$$
\begin{aligned}
& \text { المخاطر المغطاة و المخاطر المستبعدة في التأمين من } \\
& \text { المسؤولية المدنية في المجال الطبي } \\
& \text { أ. سعيد سالم عبد الله الغامدي }
\end{aligned}
$$


المخاطر المغطاة والمخاطر المستبعدة في التأمين من المن المن

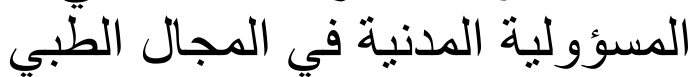

أ. سعيد سالم عبد الله الغامدي

المقدمة:

يُعدّ التأمين نظام قانوني يلتزم فيه المؤمَّن له بنصيب مالي ويدفع على أقساط

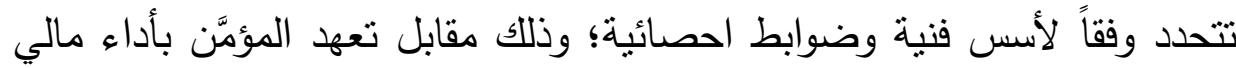

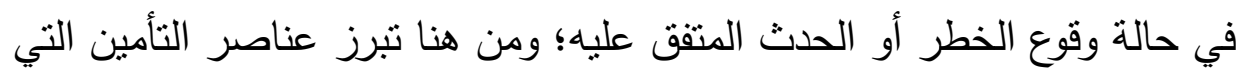

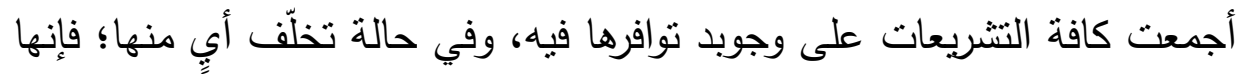

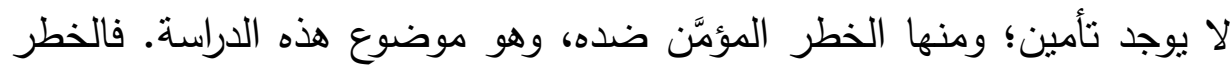

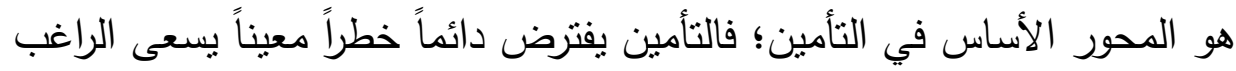

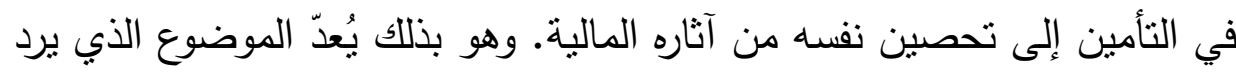

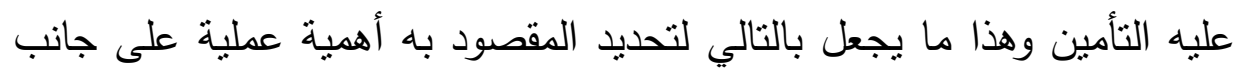

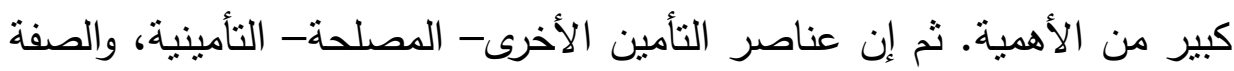
التعويضية - ترتبط ارتباطاً وثثقاً بمدى الطر المؤمَّن منه. ومن أنواع الأنساع الأخطار

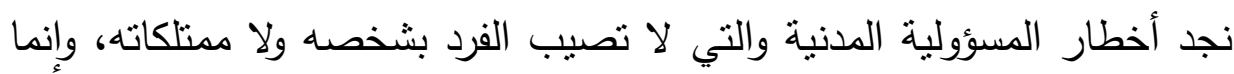

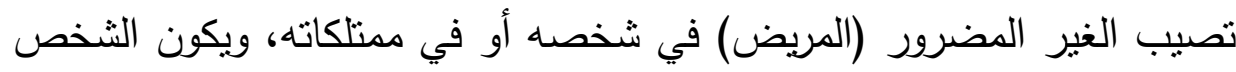

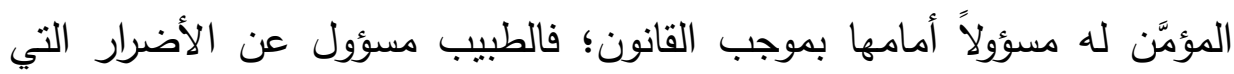

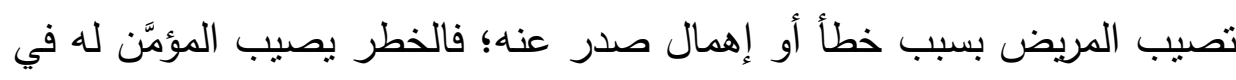

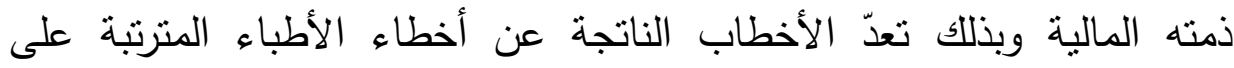

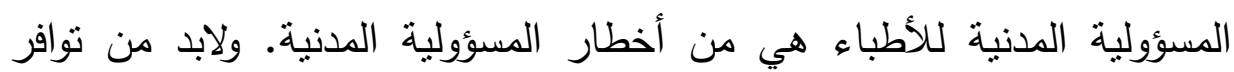
شروط جوهرية في الخطر محل عقد التأمين؛ ومنها: أن يكون الخطر خطراً

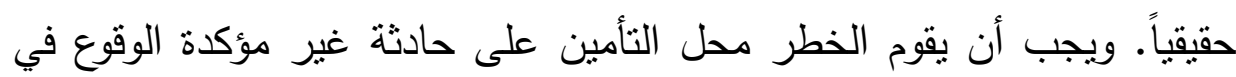

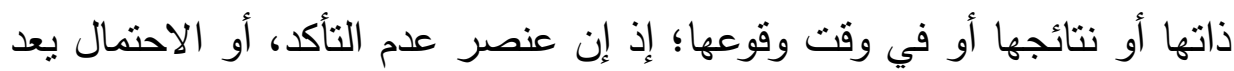

$$
(\text { ro. })
$$


أ. سعيد سالم عبد الله الغامدي

من جوهر التأمين، كالخطأ الطبي أثناء معالجة المريض الذي يمكن أن يقع أو لا يقع. وأن يكون الخطر ناجماً عن حادثاً مشروعاً غير مخالفاً لفكرة النظام العام والآداب؛ فالعمل الطبي الذي يخشى الطبيب عند ممارسته له أن يترتب عليه

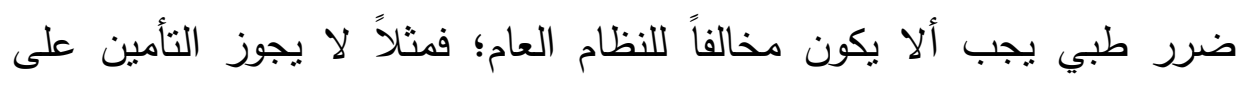
الضرر الناجم من عمليات الاجهاض وكذلك من شروطه أن يكون ناتج عن لهن حادث غير متعلق بمحض إرادة العاقدين خصوصاً المؤمن له.

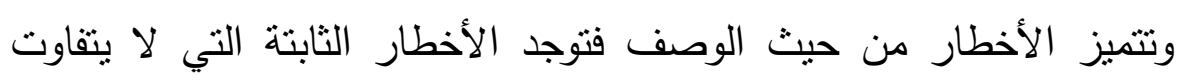
احتمال وقوعها تفاوتاً كبيراً خلا مدة التأمين أي أن ظروف تحققه تظل ثابتة خلال فترة زمنية معينة. أما الأخطار المتغيرة فهي الأخطار التي تتفاوت وتختلف فرص وقوعها أو تحققها من فترة لأخرى من فترات التأمين أي أن درجة احتمال تحقق الخطر تتغير خلال مدة التأمين إما بالزيادة أو النقصان. وهناك الخطر المعين وهو الذي يرد على محل معين وقت التأمين، كالتأمين على مرضى القلب وقت العقد، أما الخطر غير المعين فينصب على محل غير محدد وقت إبرام العقد ولكنه يتحدد عند تحقق الخطر كالتأمين ضد الأضرار التي تصيب المرضى في مؤسسة علاجية معينة. تمهيد وتقسيم:

إن شركات التأمين تقوم بتقدير دقيق جداً للأخطاء الطبية؛ نظراً لجسامنها؛ ويأتي هذا التدقيق تفادياً لتغطية بعض أشكال هذه المسؤولية تلافياً لنتائجها في المستقبل. وبذلك ييرز في مجال التأمين من المسؤولية المدنية الطبية أهمية تحديد نطاق الأخطاء الطبية التي نتكل خطراً يُؤمَّن عليه. كما أن أهمية تحديد هذه الأخطاء جاءت نتيجة؛ لكثرة صور الأخطاء الطبية، وأن منها لا تقبل شركات التأمين تغطية ما ينشا عنها من مسؤولية إما بصورة مطلقة وإما نظير أقساط 
مرتفعة، وبذلك يتم تقسيم هذه الدراسة إلى مبحثين: يخصص الأول: للمخاطر

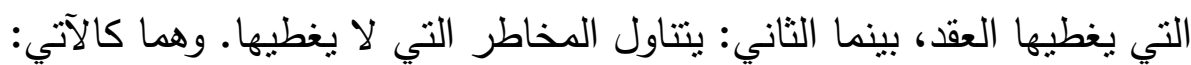
المبحث الأول: المخاطرالتي يغطيها التأمين من المسؤولية الطبية. المبحث الثاني: الأخطاء المستبعدة من التأمين من المسؤولية الطبية.

$$
\text { المخاطر التي يغطيها التأمين من المسؤولية في المجال الطبي }
$$
إن من أهداف التأمين من المسؤولية الطبية هو أن يغطي الآثار المالية المئية

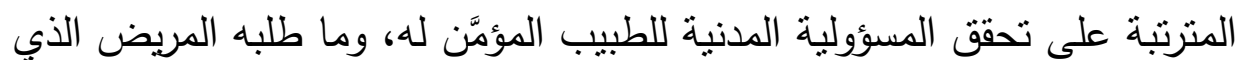
أصابه الضرر بالتعويض، ونظراً لجسامة الأضرار الجسمانية الناتجة من الأخطاء

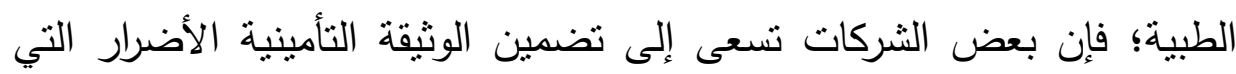

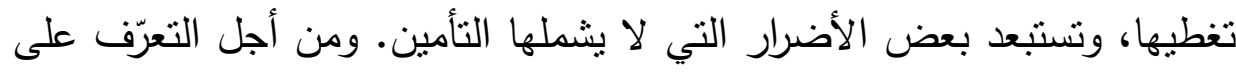

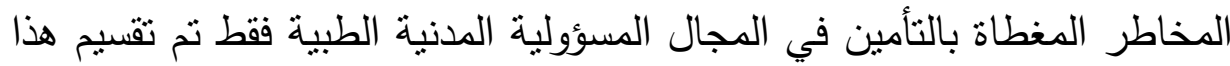
المبحث إلى ستة مطالب وهي كالآتي: المطلب الأول: شمول التأمين لنوعي المسؤولية المدنية الطبية. المطلب الثاني : تغطية التأمين لمسؤولية الطبيب الناتجة من فعله الثخصي. المطلب الثالث: تغطية التأمين للأخطاء الناجمة عن تابعي الطبيب. المطلب الرابع: تغطية التأمين للأخطاء التي تقع من الطبيب البداءيل للطبيب تلبيب المعالج (المؤمَّن له). المطلب الخامس: تغطية التأمين للمسؤولية الناجمة عن حوادث الآلات والأجهزة

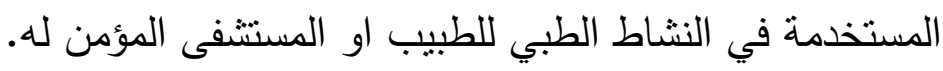
المطلب السادس: تغطية التأمين للمخاطر الناتجة من تحقق مسؤولية بنك الدام.

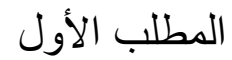

شمول التأمين لنوعي المسؤولية المدنية الطبية

$$
\text { (ror) }
$$


المخاطر المغطاة والمخاطر المستبعدة في التأمين من المسئولية المدنية في المجال الطبي سالم عبد الله الغامدي

إن الأصل في طبيعة المسؤولية الطبية أنها عقدية(') إلا أنها ليست كذلك في

جميع الحالات؛ فمن المكن أن تكون مسؤولية تقصيرية في العديد من الفروض، إذ لا يمكن تصور وجود عقد(r) لتخلف رضا المريض(r)، وذلك في حالة أن يتذخل الطبيب من تلقاء نفسه، لإنقاذ جريح، أو أن يمتتع الطبيب بغير مبرر مشروع عن إنقاذ مريض()؛؛ لذا يجب أن يغطي عقد التأمين من المسؤولية الطبية لإنهاء نوعي المسؤولية المدنية للطبيب؛ بحيث لا يقتصر على إحداهما دون الأخرى(ْ).

(1) سليمان مرقس، الوافي في شرح القانون المدني: في الفعل الضار والمسؤولية المدنية،

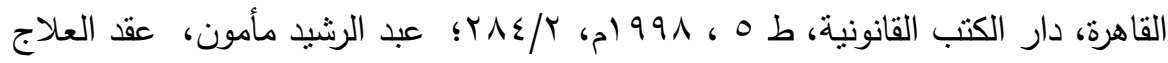

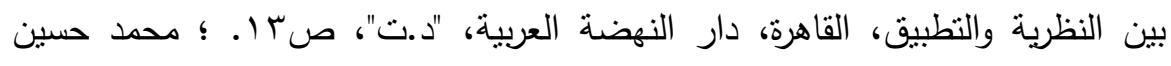

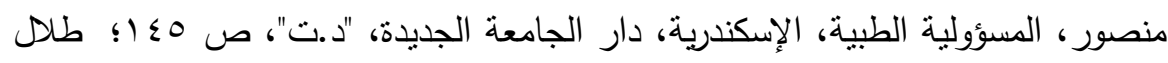
عجاج، المسئولية المدنية للطبيب : دراسة مقارنة، طرابلس، لبنان، المؤسسة الحديثة الإنة

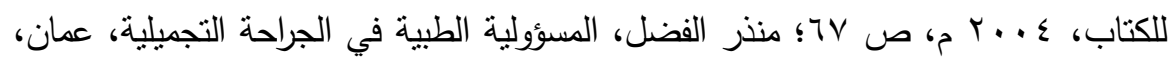
مكتبة الثقافة، طץ، 990 ام، ص مبر؛ بسام محتسب باله، المسؤولية الطبية المدنية

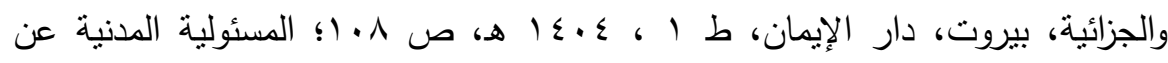
التجارب الطبية في ضوء قواعد المسئولية المدنية للأطباء، القاهرة، دار النهضة النهاء العربي، (Y) 199.

(r) عبدالراضي محمد هاثم، المسؤولية المدنية للأطباء، ص به؛ طـلال عجاج، المسؤولية

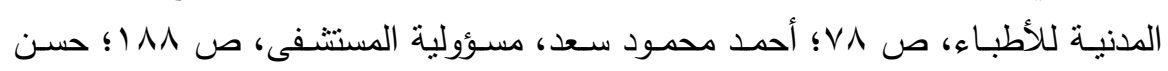

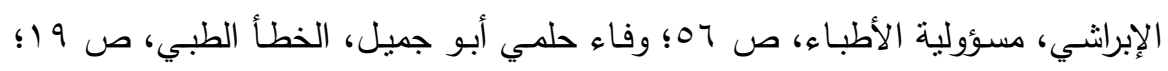
علي حسين نجيدة، التزامات الطبيب، ص ع بـ؟؛ محمد هاشم القاسم، المسؤولية الطبية،

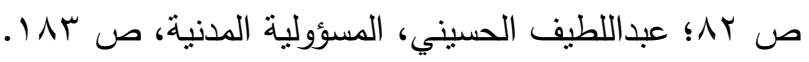

(3) Lambert Faivre droit du Dommage Corporel, Systeme d'indemnistation, 5C, edition Daloz, 2004, P. 270.

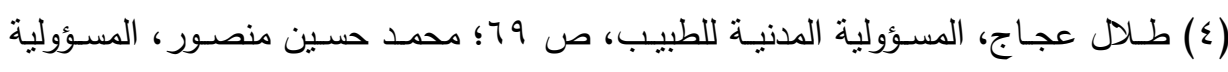

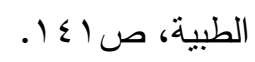

(5) Lambert - Faivre: Droit du dommage Corporel, Systemes d'indemnisation, P: 270 أحمد الصرايرة، التأمين من المسؤولية المدنية، ص IVV

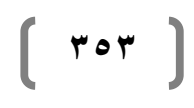


وضمان المؤمَّن للمسؤولية العقدية الطبية قد يكون مطلقاً؛ بحيث يغطي ثلك المسؤولية منى تحققت ، أياً كانت جسامة الأخطاء التي تقع من هذا الأخير مع الأخذ في الاعتبار عدم جواز التأمين من الخطأ العددي - وهو فرض يندر وقوعه عملاً، وقد يكون مقيداً بحيث لا يلتزم المؤمن بتغطية الأضرار الناشئة عن الخطأ الجسيم من جانب المؤمن له - الطبيب - إذ على الرغم من جواز

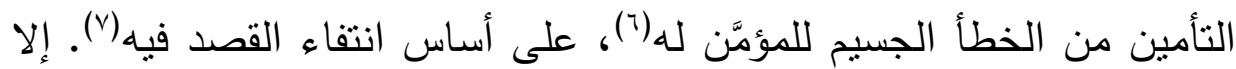
أن المؤمّن يستطيع أن يقبد ضمانه لمسؤولية المؤمَّن لهـ- الطبيب- باستبعاد منل مئل هذا الخطأ من الضمان، أو أن يضمن بعض الأخطاء الجسيمة دون البعض له الآخر. ولا ثتور مشكلة ما إذا نص العقد صراحةً على أن الضمان يغطي المسؤولية العقدية والمسؤولية التقصيرية للطبيب المؤمَّن له على السواء(^).

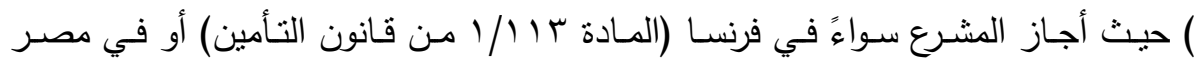

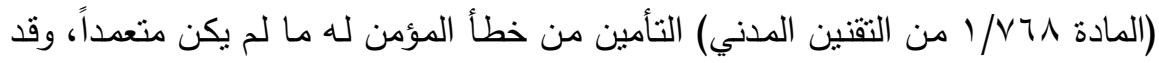

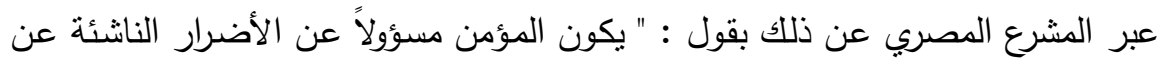

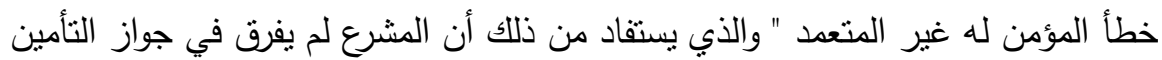
من الخطأ غير العددي بين كون الخطأ يسيراً أو جسيماً.

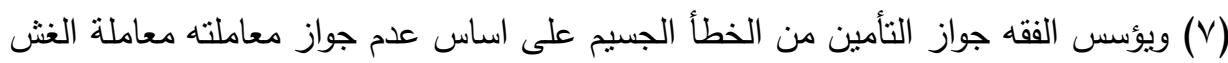

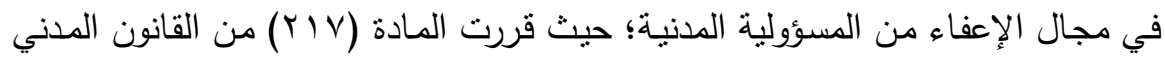

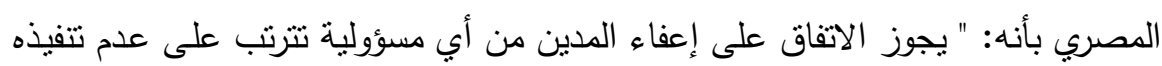

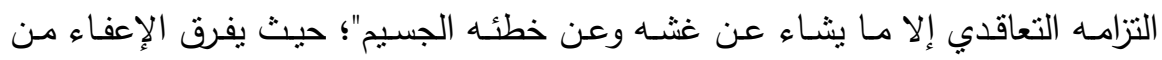
المسؤولية عن التأمين من المسؤولية، في أن الأول يهدف إلغاء إعناء المسؤولية تماهـاً بينما

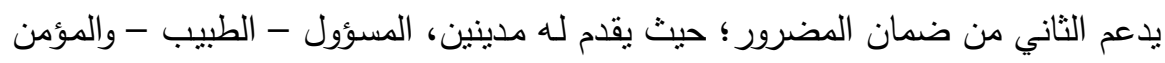

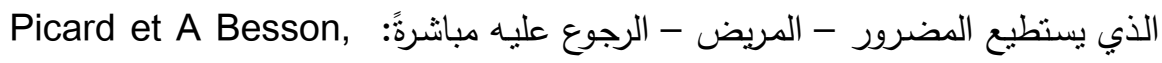
Les assurnces terrestres, tome , 1 - La contrat d'assurance, sedition, Paris, 1982, P. 308.

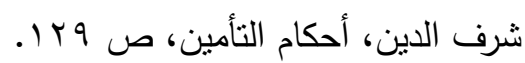

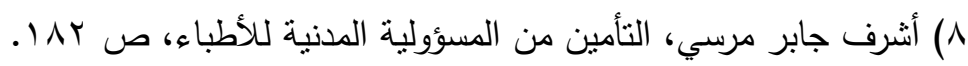


المخاطر المغطاة والمخاطر المستبعدة في التأمين من المسئولية المدنية في المجال الطبي سالم عبد الله الغامدي

وحتى في حالة ما إذا كان العقد يتضمن النص على أنه يغطي مسؤولية الطبيب المدنية، دون توضيح مسؤولية عقدية أم تقصيرية؛ فإنه يجب أن يغطي

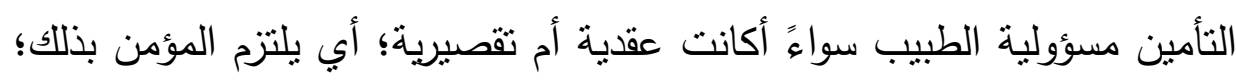

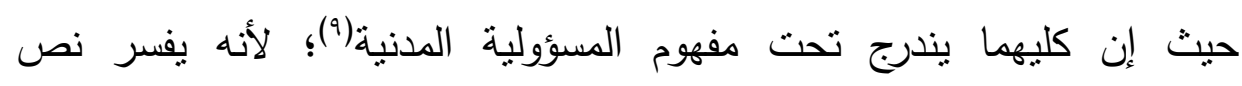
المسؤولية المدنية بأنه يغطي المسؤولية التقصيرية؛ فإن هذا بحد بقدٍ كبير من الضمان الذي يقدمه التأمين من المسؤولية وبخاصة في المجال الطبي؛ حيث في الغالب إن مسؤولية الطبيب هي مسؤولية عقدية(·')، ومعظم الفقه قد أثنار إلى فئ أنها عقدية.

والقاعدة أنه من الجائز للشخص أن يؤمَّن لدى شخص آخر (شركة تأمين)

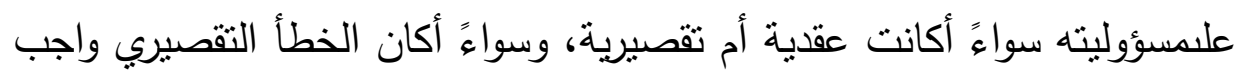
الإثبات أم مفترضاً، وسواءً أكان الفعل الضار الواجب الإثبات يسيراً أم جسيماً، بشرط ألاًّ يكون متعدداً؛ لأن التأمين على الفعل الضار المتعدد يؤدي إلى الغش، كما يجوز أن يؤمَّن الثخص على المسؤولية عن فعل الغير حتى لو كان فعل الغير متعداً؛ لأن

الغش بهذه الحالة ينتفي دن جانب المؤمَّن (1').

مدى شمول التأمين عن المسؤولية الطبية بدون خطأ

طالب الفقيه الفرنسي (تونك) بأن يكون التأمين من المسؤولية الطبية شاملاً المخاطر الطبية كافة؛ بحيث يغطي مسؤولية الطبيب بدون خطأ مبرر؛ ذلك أن بان بون

(9) أحمد الصرايرة، التأمين من المسؤولية المدنية الطبية، ص V ا ا؛ عدنان سرحان، مسؤولية

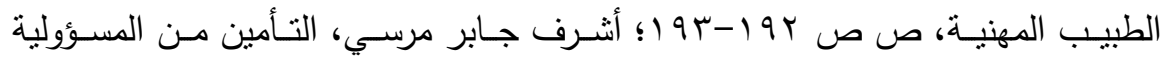

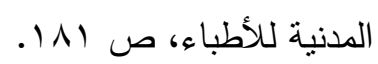

( • (1) أثرف جابر مرسي، التأمين من المسؤولية، ص اه (1؛ خالد الدعجة، المسؤولية المدنية

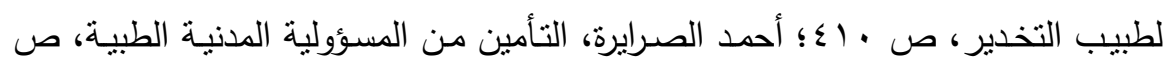

$$
\text { .IVA }
$$

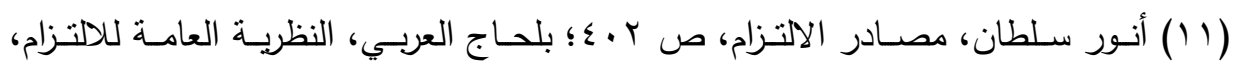

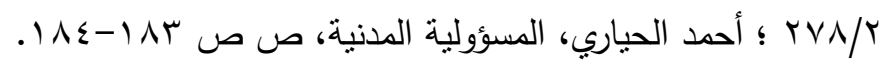


التأمين الخالي من المسؤولية ينحاز إلى الأطباء على حساب المرضى، ويمكن

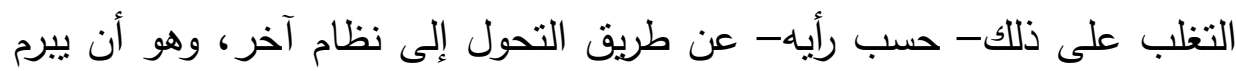

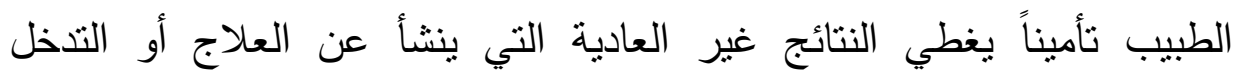

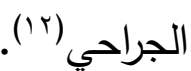

ولا يعني الأخذ بمبدأ المسؤولية بدون خطأ الاستغناء عن الخطأ كلياً والبحث عن معيار آخر ؛ لأن ذلك يخالف القواعد المستقرة في المسؤولية، ويرى العميد

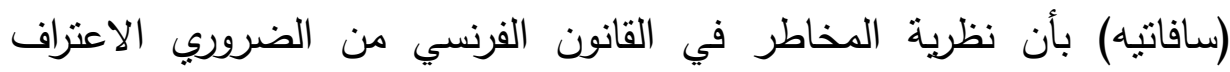

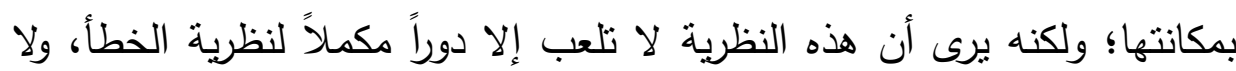

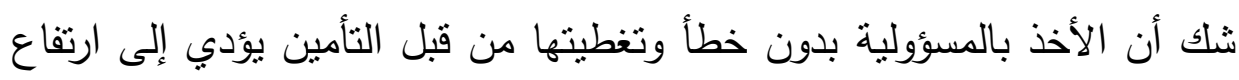

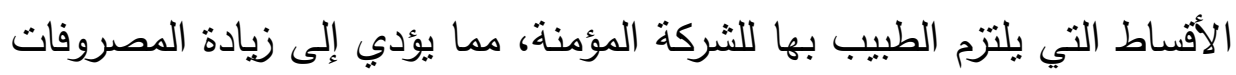

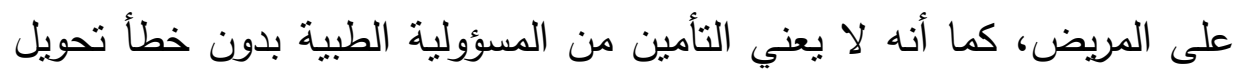

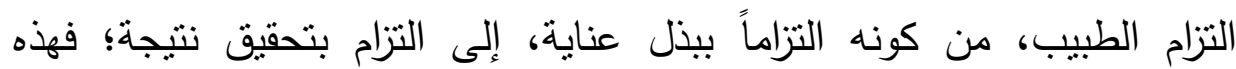

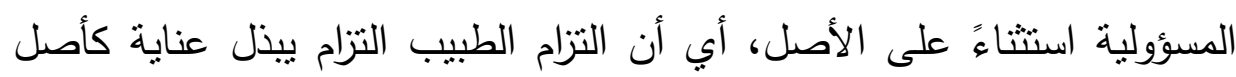
عام، والنتيجة استثناءً عليه('ا"). فقد أخذ المشرع الفرنسي بالتأمين الإجباري من المسؤولية في بعض المجاء المالات

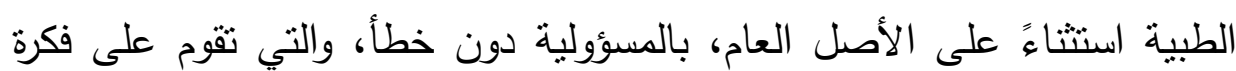

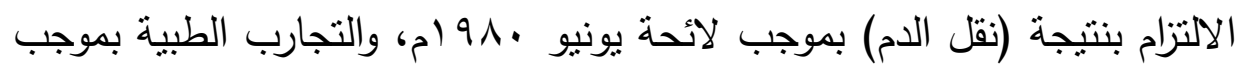

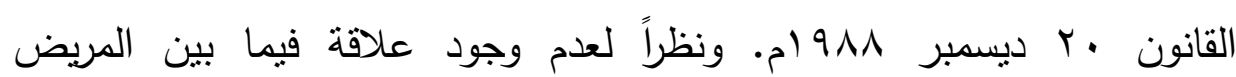

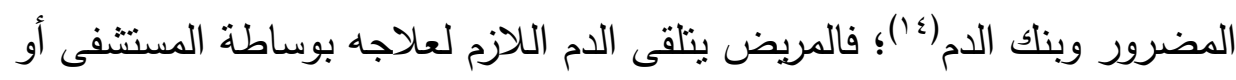

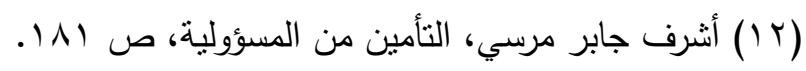

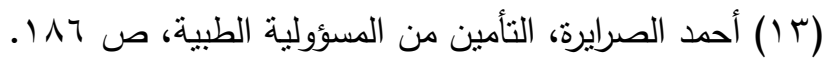

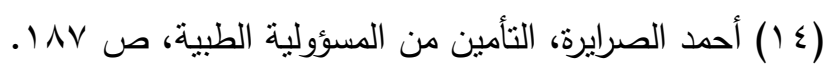


المخاطر المغطاة والمخاطر المستبعدة في التأمين من المسئولية المدنية في المجال الطبي

الطبيب المعالج، فالعلاقة تكون بين بنك الدم والطبيب المعالج أو المسنتفى الذي يتولى العلاج في إطار عقد التوريد الذي يكون بين المسنتفى وبنك الدم. فالمريض هنا لا بستطيع الرجوع إلى المستشفى أو الطبيب المعالج على الى أساس المسؤولية العقدية إلا على الجهة التي تتولى علاجه (سواءً أكانت مسنتفى إلى عاماً أم طبيباً خاصاً)، وذللك بناءً على عقد العلاج المبرم بينهما، ثم تقوم تلك لك الجهة بالرجوع إلى المركز بناءً على عقد التوريد، أما فيما يتعلق برجوع المريض إلى بنك الدم، فقد كان القضاء الفرنسي يقرر مسؤولية بنك الدم على أساس تقصبري. وقد كان هذا الحكم بمناسبة دعوى تم رفعها على مستشفى قام بنقل دم حصلت عليه من المركز الوطني لنقل دم تبرعت به سيدة مصابة بمرض الزهري مما نرتب عليه نقل العدوى إلى المريض الذي قام برفع الدعوى على المركز على

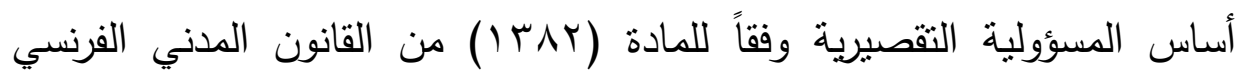
وقضت محكمة استئناف باريس في جr أبريل 19 إم(10) بمسؤولية المركز مسؤولية تقصيرية، وذلك لقيام الخطأ والذي بتمثل في عدم الأخذ بالاحتياطات اللازمة وفق الأصول العلمية من أجل تفادي الدم الملوث. وبعد الطعن في القرار

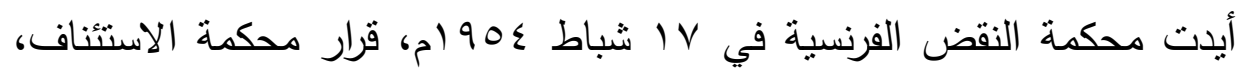
ولكن على خلاف بينهما في التأسيس؛ حيث أقامت محكمة النقض مسؤولية بنك

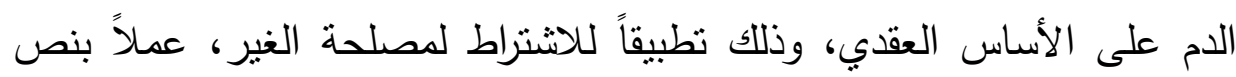

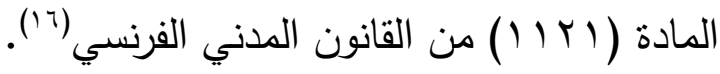

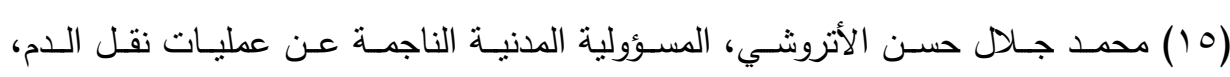

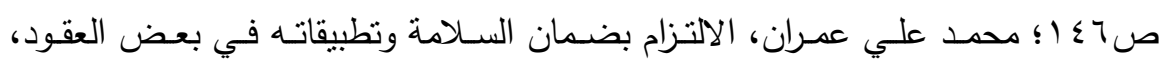
صr.1. (7 (1) يقابل هذا النص في القانون المصري المدني المادة (ع (1). $(r \circ v)$ 
فهذا الحكم أقر من جهة الطبيعة العقدية للعلاقة بين بنك الدم والمربض ه. والمتمثلة بنقل دم سليم وإن التزم بتحقيق نتيجة. وعليه فإن على شركة التأمين تغطية مسؤولية بنك الدم سواءً أكانت تقصيرية أم عقدية. كما ونصت المادة (TTV) من قانون الصحة الفرنسي على: " يقع على عاتق مركز نقل الدم التزام بالسلامة بتحقيق نتيجة في مواجهة

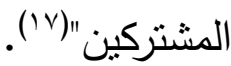

فهذا النص أقر المسؤولية الموضوعية على عاتق المركز لصالح المتبرع بالدم(^). وما دام المريض قد أصابه ضرر، وهذا الضرر حصل بعد تلقيه العلاج فهذا يعد قرينة قوية على أن الضرر ناتج من خطأ، وعلى شركة التأمين يقع عاتق نفي الخطأ، بمعنى أن الخطأ مفترض ناتج عن النشاط الطبي؛ لأن العمل الطبي عمل دقيق، وكذلك جسم الإنسان دقيق في تركيتنه(9').

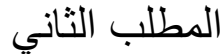

تغطية التأمين لمسؤولية الطبيب الناتجة من فعله الشخصي

ينحصر التأمين في نطاق النشاط المهني الطبي الذي يمارسه الطبيب أو مساعدوه، سواءً مارس هذا النشاط في المسنتفى أو في العيادة، أو المركز الصحي؛ حيث لا أثز للمكان الذي يزاول به النشاط الطبي المختص، إذ المعتبر هو خروج الطبيب عن نشاطه الطبي المحدد في عقد التأمين في مرحلة

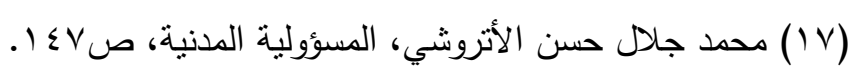

(18)Le Centre de transfusion sanguine est tenue d'une obligation de securite, De resultat, a l'egard de ses donneures".

(19)Bruno Esnault: "Quelles solution aux Problemes d'indemnisation des victims Laccidents therapeutique responsabilite objective et أحمد الصرايره، التأمين من المسؤولية .

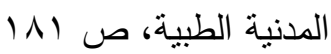

$$
(r \bullet \Lambda)
$$


المخاطر المغطاة والمخاطر المستبعدة في التأمين من المسئولية المدنية في المجال الطبي

التشخيص،(·) أو مرحلة العلاج، أو خلال إجراء عملية جراحية، أو خلا

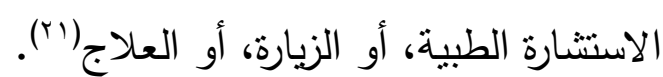

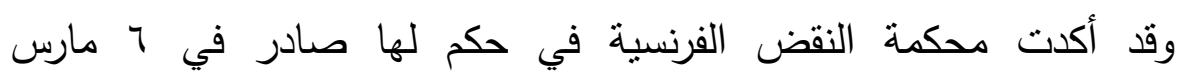
§99 (م/r(r) على ذلك في دعوى، ملخصها: أن طبيباً أخصائياً في أمراض الفم أجرى عملية ختان لطفل حديث الولادة، ترتب عليها حدوث نزبف لهذا الطفل، فقام الطبيب بعمل بعض الإسعافات له، ووعد والديه بالرجوع إليه في اليوم الثاني، إلا أنه لم يعد إلا بعد مضي بام ساعة، وكانت حالة الطفل قد تفاقمت؛ حيث

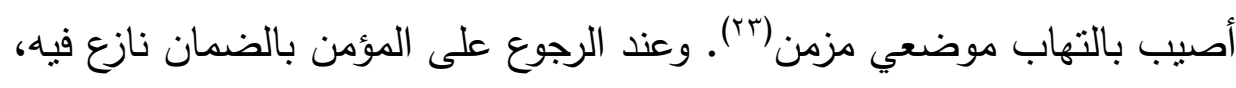
وحين عرض الأمر على محكمة استئناف باريس قضت بتاريخ ب99 (م، بتقرير مسؤولية الطبيب المؤمن له، واستبعاد ضمان المؤمن، على بلى أساس أن النشاط الذي يغطيه عقد التأمين المبرم مع الطبيب المؤمن له، هو لهونيز لهونه نشاطه المتعلق بأمراض الفم دون سواه، وهو نشاطه المأذون له قانوناً

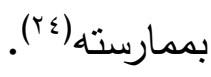

ولكن الطبيب قام بالطعن لدى محكمة النقض، وقضت المحكمة برفض

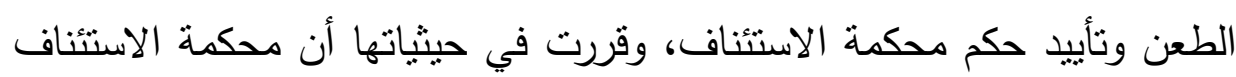
قد ذهبت إلى أن محل عقد التأمين المبرم بوساطة الطاعن- الطبيب المؤمن لهكان محدداً بتخصصه في الطب - أمراض الفم - وأنه أي الطاعن لم يعلن

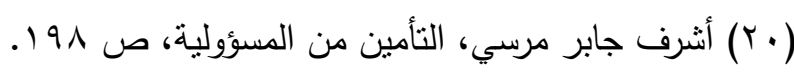

$$
\begin{aligned}
& \text { ؛ }
\end{aligned}
$$

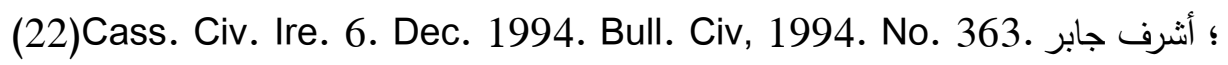

مرسي، من المسؤولية، 191. (191.

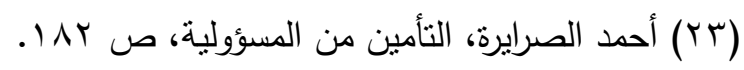

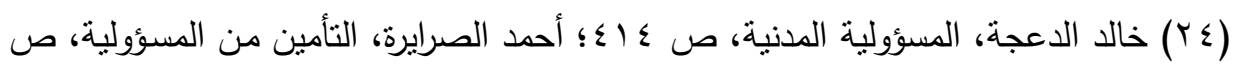


للمؤمن عن ممارسته لنشاط آخر ، إلا بعد تحقق الكارثة، ولما كان هذا الأخير لا يدخل في نطاق الضمان فإن الطعن غير مقبول(ror). كما أكدت محكمة النقض الفرنسية في أكثر من حكم حديث لها، مبدأ انحصار الضمان في حدود النشاط المعلن إلى المؤمن، فقضت في 9 ب أغسطس V99 ام(Tr) بأن ضمان المؤمن لا يمكن أن يطبق على الكارثة التي تحدث بمناسبة نشاط آخر للمؤمن له، بخلاف النشاط المعلن إلى المؤمن(Y「r)، كما

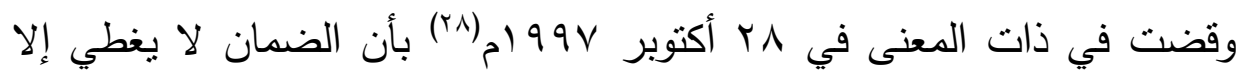
النشاط المهني المعلن إلى المؤمن(؟9). المطلب الثالث تغطية التأمين للأخطاء الناجمة عن تابعي الطبيب إن التأمين من المسؤولية الطبية يمكن أن يغطي الأخطاء التي تقع من التابع،

الذي يسمح له الطبيب المعالج بالتذخل في العلاج(·r). كما ويشمل التأمين أيضاً ما يصدر من المتدرب الذي لم يمارس المهنة، ما لما لهاب دام الطبيب قد استعان به أثثاء قيامه بالعمل، كما نتمل الأخطاء الثخص الذي

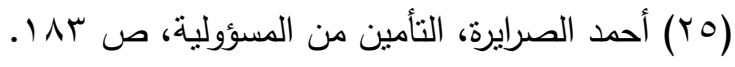

(26)Cass. Civ: 29 avr. 1997. R.C.A. no. 7-8 Juill- a'out 1997, Comm.

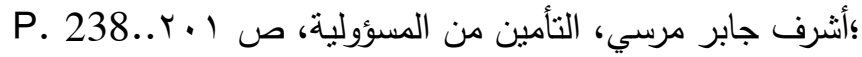

(27)La garantie de L'assurance ne peut s'appliquer a un sinister d'un ؛ أحمد الصرايرة، التأمين من "activite autre que celle declares par l'assure"

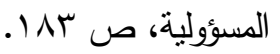

(28)Cass Ire civ. 29 Oct. 1997. R.C.A. no 2 fev 1998, P. 6.

(29)La ne concerne que le secteune d'activite Professionelle declare a

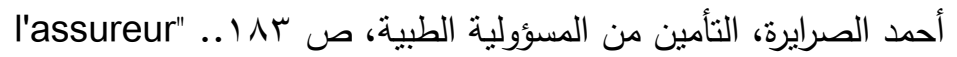

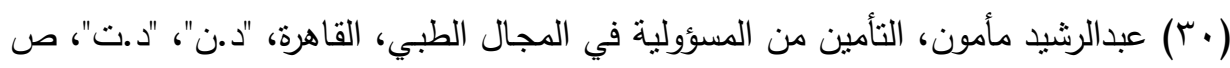

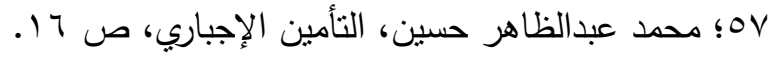

$$
(r q .)
$$


المخاطر المغطاة والمخاطر المستبعدة في التأمين من المسئولية المدنية في المجال الطبي

لم يمارس المهنة، ما دام الطبيب قد استعان به أثناء قيامه بالعمل، كما تشمل الأخطاء الثخص الذي يضعه المستشفى تحت تصرف المريض('ا"). وقد نصت المادة ع/T/ T/ من قانون التأمين الفرنسي على أن يضمن المؤمن الأضرار والخسائر التي تقع بواسطة الأشخاص الذين يسأل عنهم المؤمن

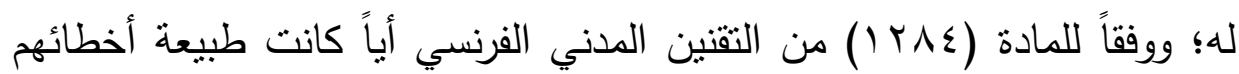
وجسامتها، وفي ذات المعنى نصت المادة (V79) من القانون المدني المصري بأنه يسأل المؤمَّن عن الأضرار التي تسبب فيها الأشخاص الذين يكون المؤمَّن له مسؤولاً عنهم مهما يكن نوع خطئهم ومداه، كما نصت على هذا الضمان الفقرة الأولى من المادة الثانية من عقد تأمين اتحاد المؤمَّنين الطبي في فرنسا

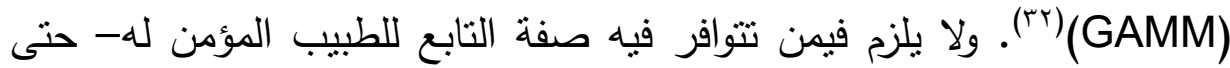
يشمل الضمان نتائج أفعاله- أن يكون عمله لقاء أجر، أو من الممكن مقطوعاً(rr)، فهؤلاء يقومون بأعمالهم تحت الرقابة المباشرة للطبيب المؤمن له، ولا يلزم النص على هذا الضمان صراحةً؛ حيث إنه لم يتم بشكل تلقائي (ء).

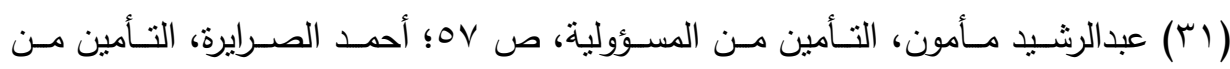

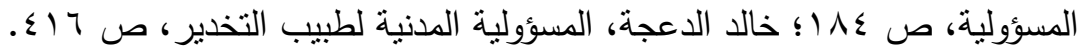

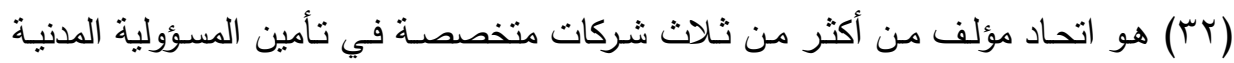
للأطباء؛ وهي: Medi - assurances Mutuelle d'assurances du corps de santé francais et Le Sou medirat "Groupe des assurances mutlulles

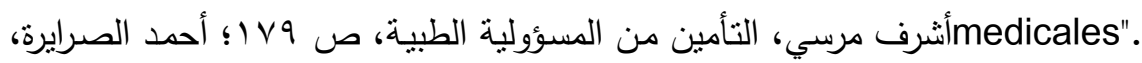

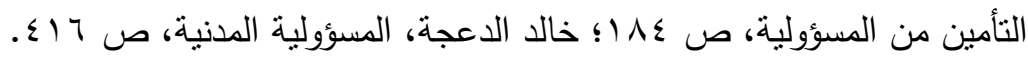
(33)A. Herande, L'assurance de resoponsabilite civile professionnelle des professions liberates et prestataires des services, 1983, p. 78. (34)De L'ste: Briere, "L'assurances de responsabilite des professions de santé" Jcp. 1981, 1, 3003.

أثـرف مرسي، التـأمين مـن المسؤولية، ص 19 1؛ أحمــ الصـرايرة، التأمين مـن المسؤولية،

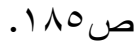

$$
(r+1)
$$


وبالرغم من أن هذا الضمان تلقائي إلا أن المؤمّن ينص عليه في العقد؛ لأنه

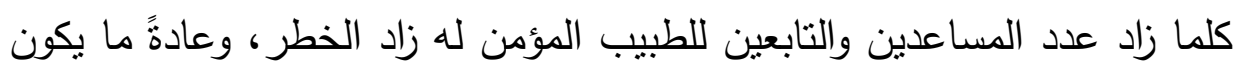

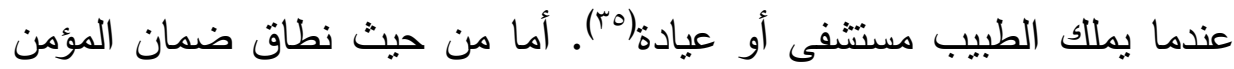

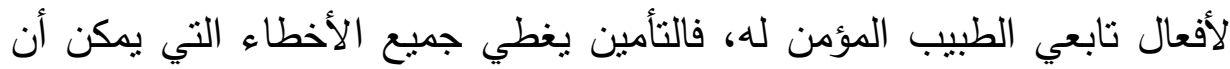

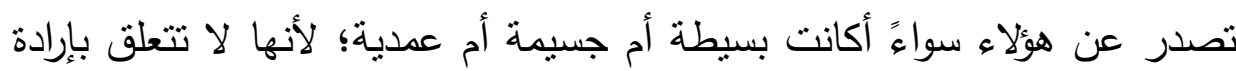

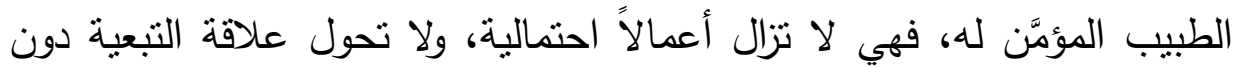

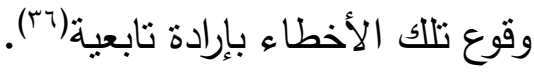

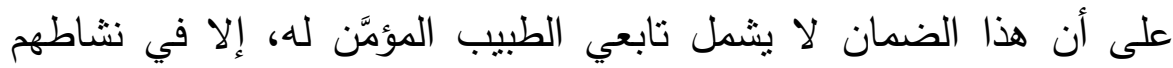
المهني المأذون لهم قانوناً بممارسته، والذي يجب أنابن لأني يكون محدداً في التأمين.

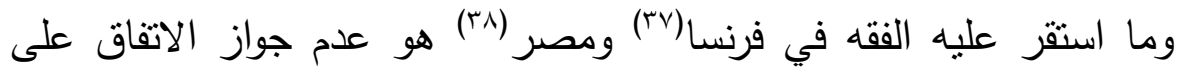
استبعاد بعض تابعي المؤمَّن له أو جميعهم، من نطاق الضمان تطبان الطبيقاً لأحكام

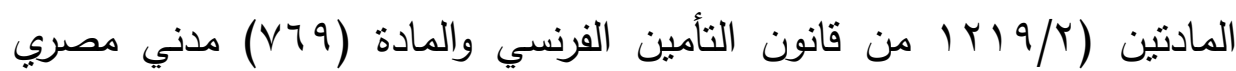

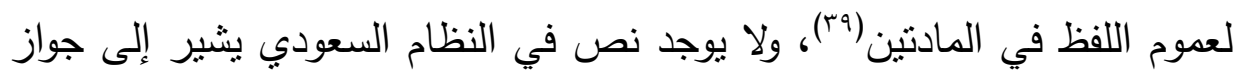

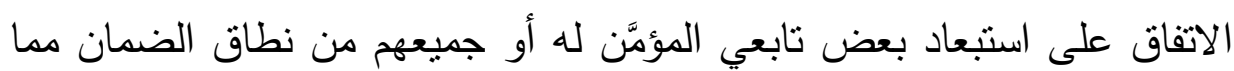

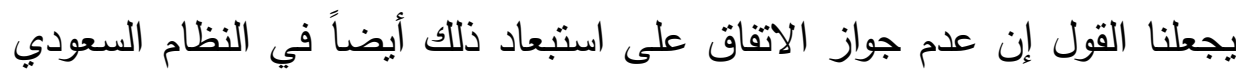

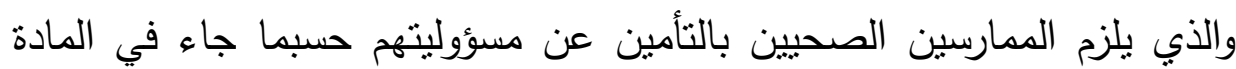

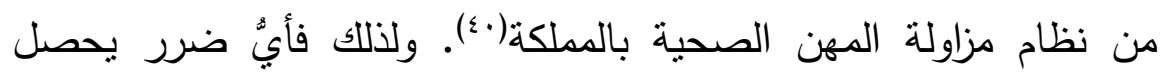

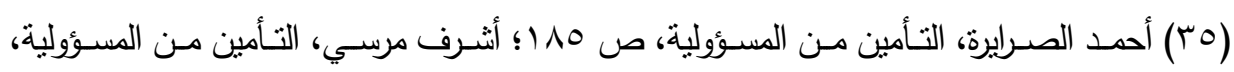

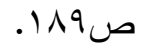

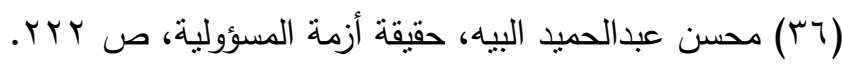
(37)Picard et Besson: "Les assurance terretres" 5 e ed, 1982, P. 308.

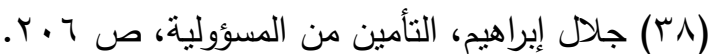

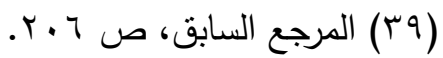

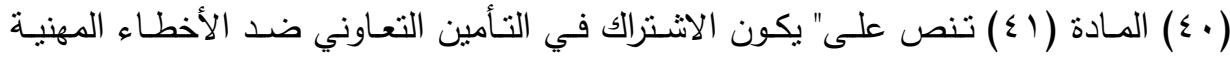

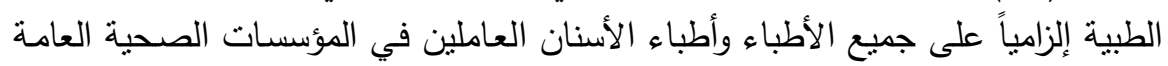

$$
\text { (rur) }
$$


المخاطر المغطاة والمخاطر المستبعدة في التأمين من المسئولية المدنية في المجال الطبي

للمريض بسبب تابعي الطبيب، يُغطى من قبل شركة التأمين المؤمّّن لديها الطبيب، ولا يجوز الاتفاق على استبعاد بعض تابعي الطبيب المؤمَّن له من

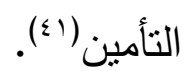

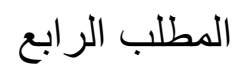

تغطية التـأمين للأخطـاء التي تقع من الطبيـب البديـل للطبيب المعـالج (المؤَّن

البديل هو طبيب يحل محل المؤمَّن له في حالة غيابه، وذلك لاستمرار الرعاية الطبية للمريض في حال غياب الطبيب المعالج. وتقوم مسؤولية الطبيب المعالج عن أخطاء البديل المهنية، على أساس سوء اختياره له، ولا يعد الطبيب البديل تابعًا للطبيب المعالج المؤمن له آنـاء.). ويجب أن ينص عقد التأمين صراحةً على أن يضمن مسؤولية البديل، وعلى الطبيب المعالج الالتزام بأخطار المؤمَّن باسم الطبيب البديل الذي حل محله، ويحدد في ذلك الالتزام المدة التي يحل فيها محله(r؟). وتسري نفس الثروط الخاصة بالطبيب المعالج المثبتة في عقد التأمين على البديل الذي حل محله، وإن كان المؤمن قد وضع قيوداً أخرى منل شرط الكفاية. كما وتشترط حتى يغطي التأمين أخطاء البديل، أن يكون غياب الطبيب المعالج

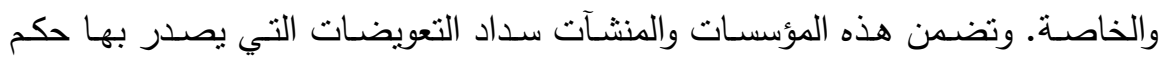

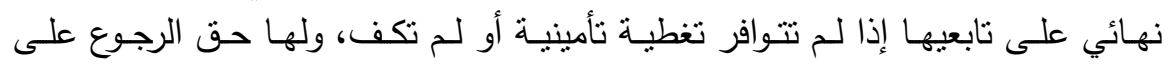

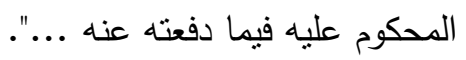

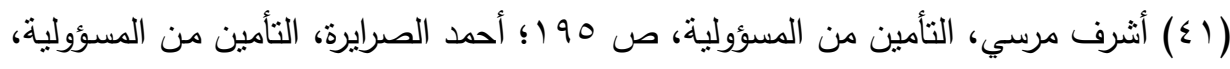
9 Y 9 .

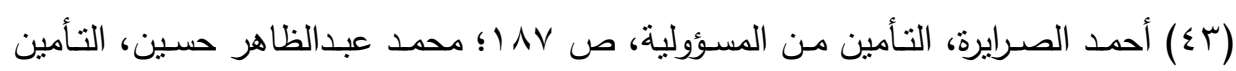

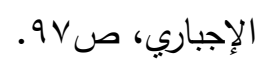


غياباً قانونياً، وإذا كان مخالفاً لذلك لا بمتد الضمان إلى أخطاء البديل(ء). ويشترط بداهةً أن يكون البديل مأذوناً له بمزاولة المهنة، وأثناء قيام البديل بعمله البه لا يجوز للطبيب المؤمن مزاولة العمل إلى جانبه إلا في حالة الضرورة(0؛). ولا لهاءله يجوز للبديل أن يبرم عقد تأمين من المسؤولية عن الخطر ذاته الذي يغطيه عقد تأمين المسؤولية المبرم من الطبيب المؤمن لهآـأه وإذا استعان الطبيب الجراح بأحد الخبراء في إجراء العملية، فإن هذا الغير إذا

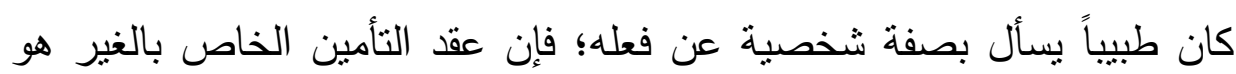

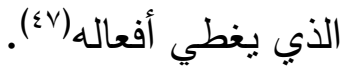

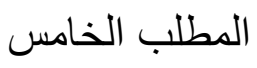

تغطية التأمين للمسؤولية الناجمة عن حوادث الآلات و الأجهزة المستخدمة في المي النشاط الطبي للطبيب او المستشفى المؤمن له اله

تترتب هذه المسؤولية على أساس المسؤولية العقدية، وذللك متى كانت العلاقة بين الطبيب والمريض علاقة عقدية، ويترتب على ذلك أن تقوم هذه المسؤولية على واجب الإثبات وليس على خطأ مفترض (^)؛؛ إذ يجب على المريض أن يثبت خطأ الطبيب، بأن يبين أن الطبيب قد استعمل جهازاً لا يجوز استعماله في منل

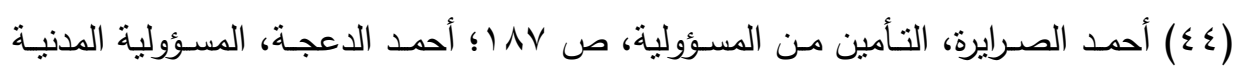

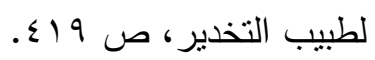

(0) أثرف جابر ، التأمين من المسؤولية، ص ص 90 1؛ كما وقد نصت على ذلك الفقرة الثانية

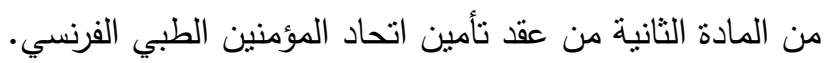

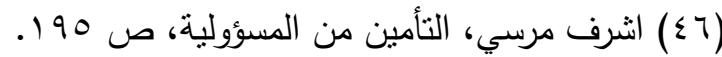

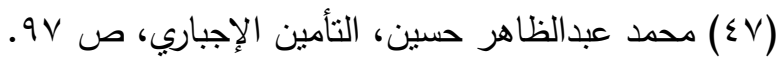

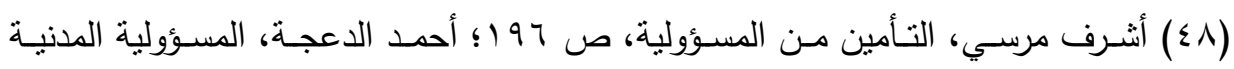

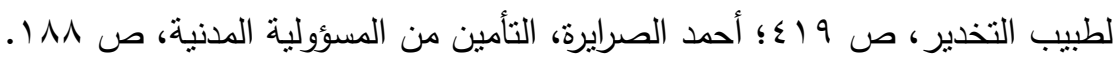


المخاطر المغطاة والمخاطر المستبعدة في التأمين من المسئولية المدنية في المجال الطبي حالة المريض التي تعالج، وتكون مسؤولية تقصيرية وهي مسؤولية عن الأثياء غير الحية إذا لم يكن هناك عقد بين الطبيب والمريض(9٪). فعقد التأمين يغطي الأضرار الجسدية التي تقع بفعل الأدوات المهنية؛ لأن

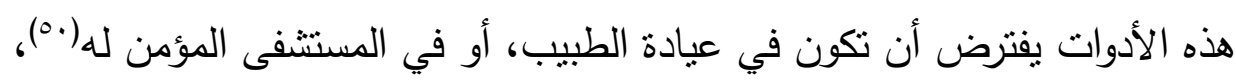
والتأمين يغطي أضرار هذه الأدوات والآلات في حالة الاصطدام بها، أو انفجارها

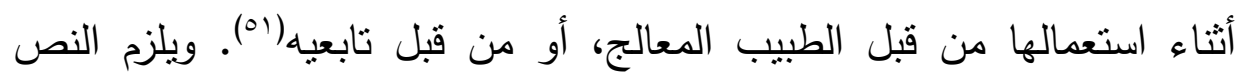
صراحةً في العقد على أنه يشمل الأضرار الناشئة عن استعمال الأدوات والآلات، التي يستعملها الطبيب المؤمَّن له في مباشرته في عمله(بها.

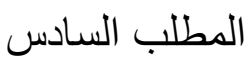

تغطية التأمين للمخاطر الناتجة من تحقق مسؤولية بنك الدم

يغطي التأمين المخاطر الناتجة من تحقق مسؤولية بنك الدم في مواجهة الأثخاص المتبرعين بالدم، والأشخاص متلقي الام، والمخاطر الناتجة من توزيع

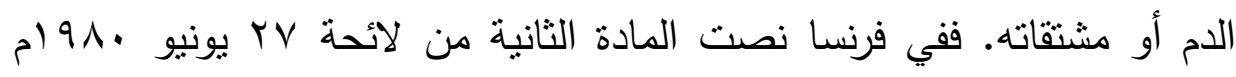
على ما يأني (or): (1) ו- المخاطر الناتجة من تحقق مسؤولية المركز في مواجهة أشخاص محددين. r- مسؤولية المركز في مواجهة الغير بوجه عام.

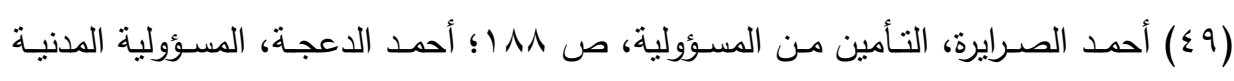

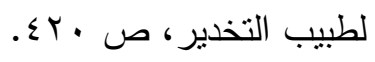

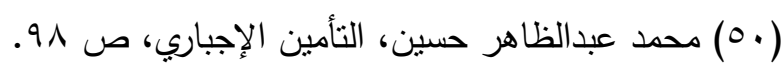

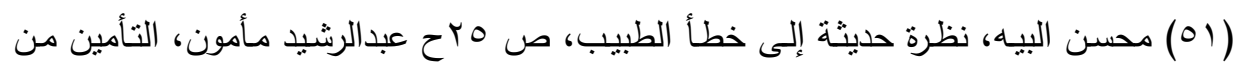

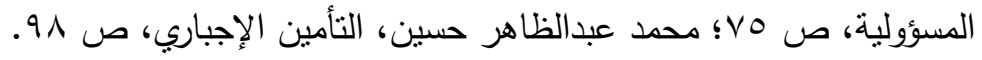

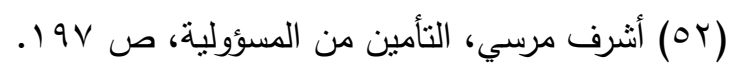

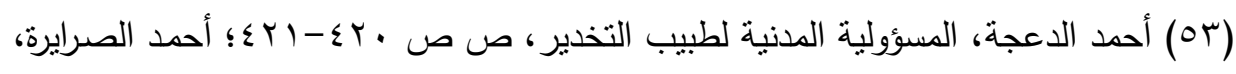

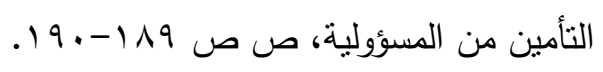


ب- المسؤولية المدنية عن حوادث التسمم الغذائي. ع - المسؤولية المدنية الناجمة عن القصور الوظيفي.

0- المخاطر الناتجة من تحقق مسؤولية المركز عن توزيع الدم أو أحد الد مشتقاته.

ولقد أدرك المشرع الفرنسي أهمية إصدار تشربع يفرض التأمين الإجباري عن نشاطات محددة في المجال الطبي ومنها التأمين الإجباري لمركز نقل الدم(ء). لقد فرض هذا النص التأمين الإجباري على مركز نقل الدم في فرنسا، وبموجبه يغطي التأمين هذه المخاطر ، فيما يتعلق بالأضرار الجسدية أو المادية والمعنوية التي تصيب المريض، ويشمل التأمين ما يأتي (00): - - أكل شخص سيتبرع بالدم أثناء سحب الدم منه، أو إصابته بأي أذىً أثناء

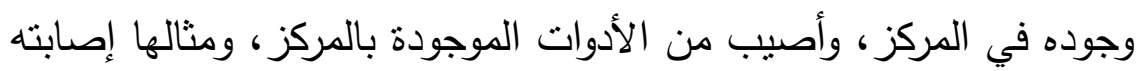
بالعدوى لأي مرض خطير نتيجة سحب الدم منه بواسطة إبرة ملوثة غير معقة. r- - كل شخص منلقي الدم، ويعني ذللك: شخص يتلقى الدم للعلاج ويلحقه الضرر نتيجة نقل الدم، أو أحد مشتقاته، يكون المركز مسؤولاً عنه وبالتالي فإن عقد التأمين يجب أن يشمله. r- الأضرار الناتجة لأي شخص نتيجة الآلات المستخدمة في المركز أو الأضرار الناتجة من أفعال العاملين بالمركز، إذ إن التأمين يغطي هذه

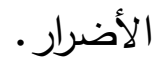

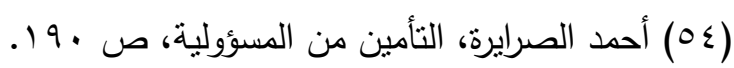

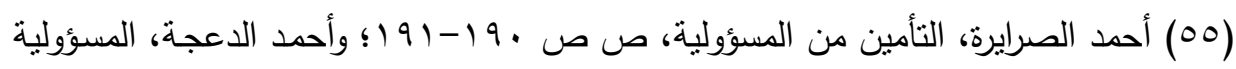
المدنية، ص الح؟ع. 
المخاطر المغطاة والمخاطر المستبعدة في التأمين من المسئولية المدنية في المجال الطبي

ع - التأمين يغطي المخاطر الناتجة من توزيع الدم ومشتقاته، وبقصد بذلك كل تسليم لوحدات الدم أو مشتقاته إلى الغير، وبيتخدم هذا الأخير هذا المنتج بعيداً عن تدخل المركز، حيث يغطي هذا التأمين الأضرار الناتجة من هن توزيع الدم.

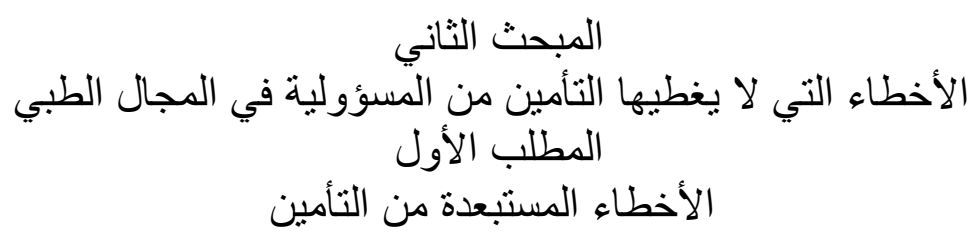

في عقد التأمين يجب أن يكون الخطر المؤمن عليه احتمالياً وليس أكيد الوقوع، كما أن على المؤمن له واجباً معيناً هو أن لا يتعدد الفعل المؤدي إلى لى وقوع الخطر، وإلا أصبح التأمين وسيلة من وسائل الهروب من المسؤولية؛ مما يتعارض مع أسس المسؤولية المدنية. لذلك فإن التأمين لا يغطي الآثار المالية للمسؤولية الجنائية (كالغرامة التي يجب على المحكوم عليه دفعها نتيجة مخالفته القوانين والأنظمة) فالطبيب الذي يخالف أي نظام وتقرض عليه غرامة فلا يحق له مطالبة شركة التأمين التي أمَّن عندها عن مسؤوليته على أخطائه الطبية. فإذا

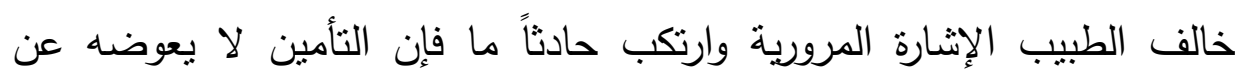
المخالفة في طبيعتها هي عقوبة نص عليها في النظام. وعلاوةً على ما سبق فإن التأمين كما يستبعد من نطاقه المسؤولية الجنائية؛ فإنه أيضاً يستبعد الخطأ العدي والخطأ التذليسي أو الغش من نطاق التأمين في المسؤولية المدنية الطبية؛ فالتأمين يغطي فقط الخطأ غير العددي للطبيب وحتى الجسيم منه والمتمنل في الإهمال، أو الرعونة، وعدم الحذر. ولقد أصبح التأمين من المسؤولية على وحئ

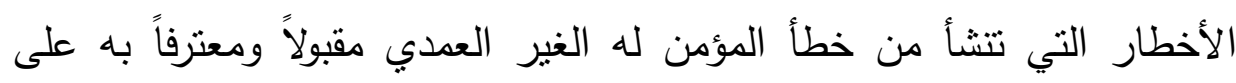
نطاق واسع، باستثناء المسؤولية الناشئة عن الأخطاء التدليسية والجسيمة التي استبعدت من نطاق التأمين.

$$
(r q v)
$$


وبذلك أصبح الخطأ غير العددي الذي لا ينشأ عن محض إرادة المؤمن له قابلاً للتأمين عليه، أما الخطأ العمدي المعلق على محض إربادة المؤي لأمن له فإنه

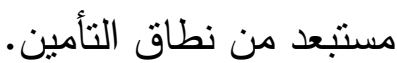

وقد جاءت المادة (V^^) من القانون المدني المصري بالنص على ذلك بقولها

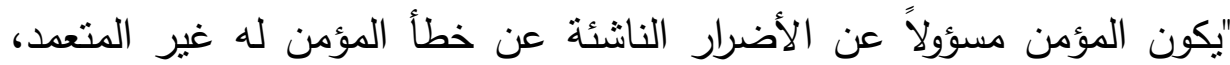

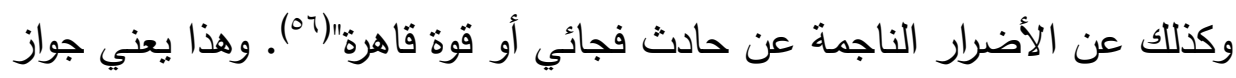
التأمين من الأخطار التي تتشأ أو تتولد من خطأ المؤمن له (الطبيب) غير الهي

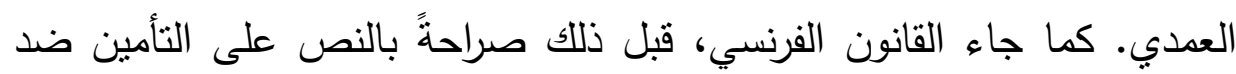

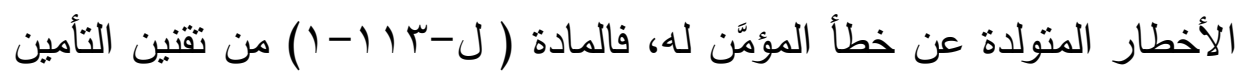

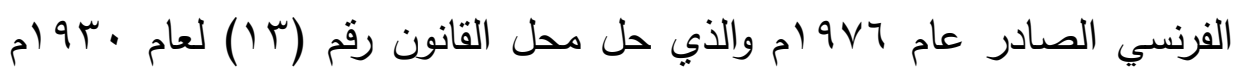

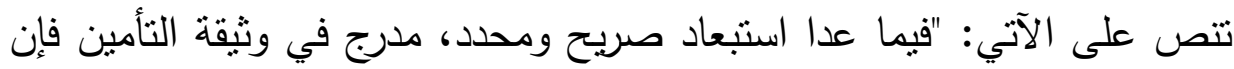

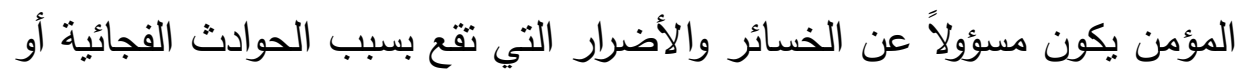
خطأ المؤمَّن له"((ov).

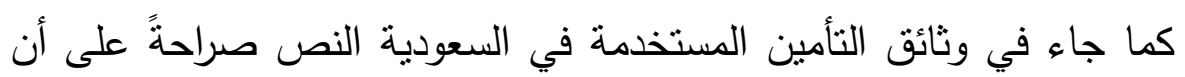

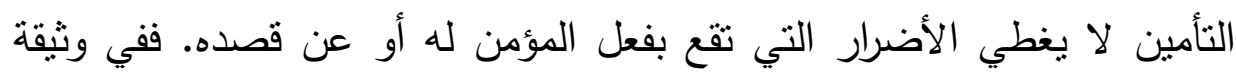

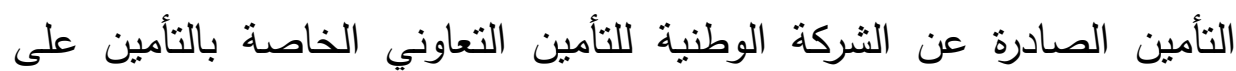

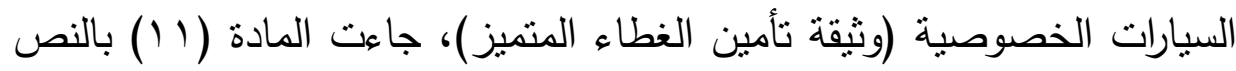

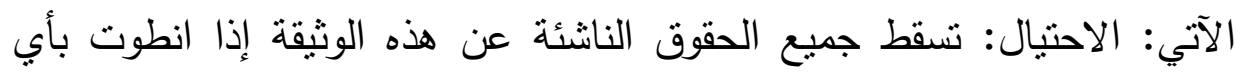

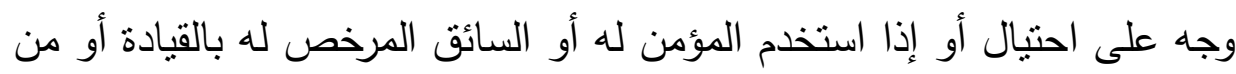

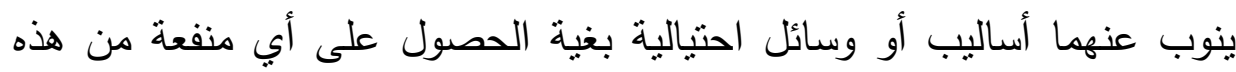

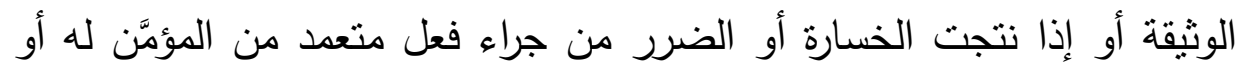


أ. سعيد سالم عبد الله الغامدي

السائق المجاز بالتواطؤ مع أي منهما". كما جاءت الفقرة (و) من المادة (؟) من

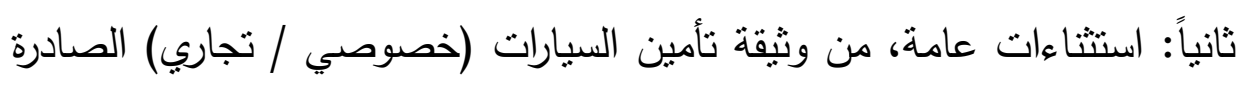

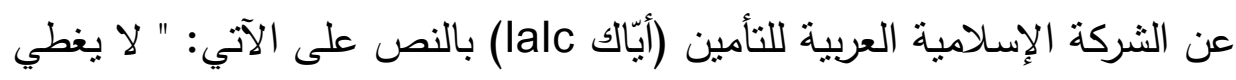

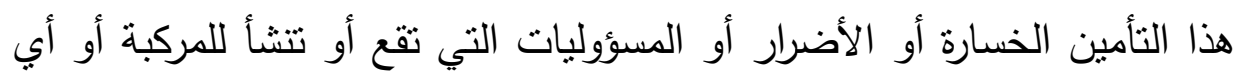

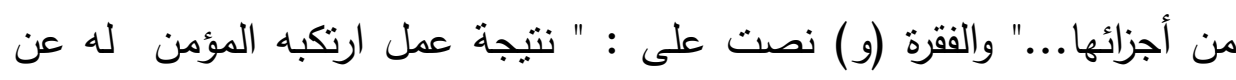

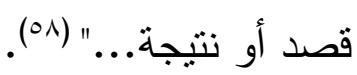

ويراعى أن هذه المواد الواردة في وثائق التأمين في السعودية تمثل عرفاً تأمينياً

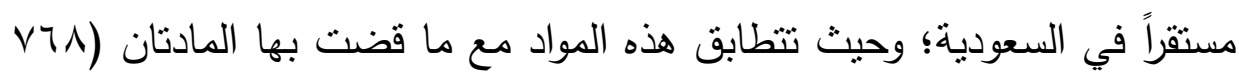

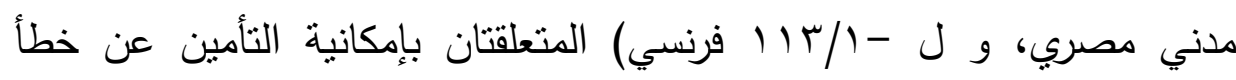

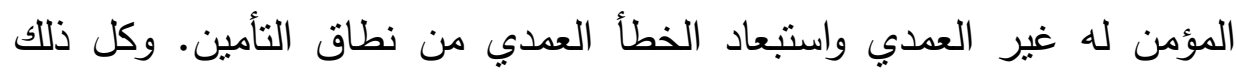
يجعلنا القول إن الخطأ العدي للممارس الطبي يستبعد من التأمين على المسؤولية الناتجة من الخطأ الطبي.

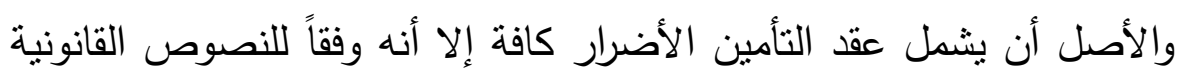

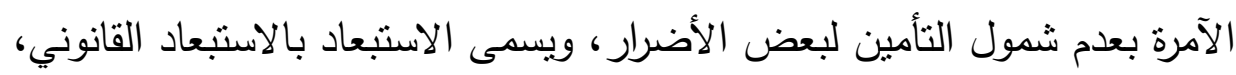

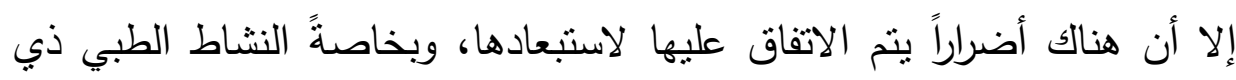

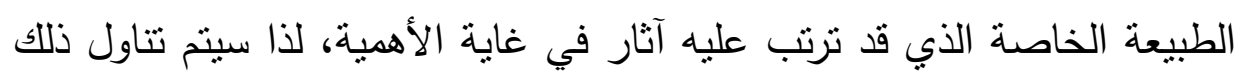

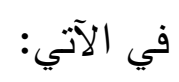

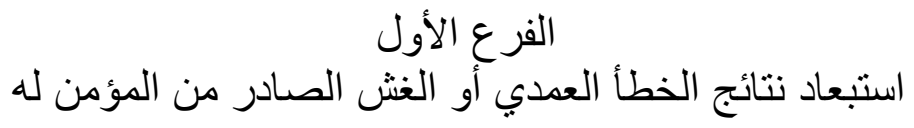

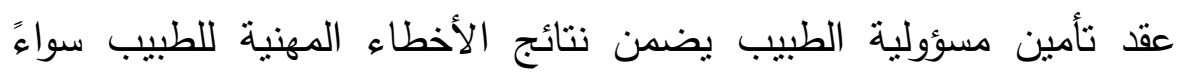

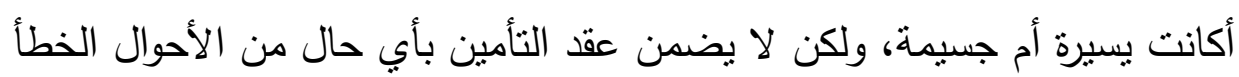


العددي للطبيب(ه9). كما أنه من الثروط الواجب توافرها في الخطر المؤمن منه، أن لا يتوقف تحققه على إرادة أي من طرفي العقد(·"). وفي النظام السعودي؛ حيث لا يوجد قانون للتأمين غير نظام السكورتاه

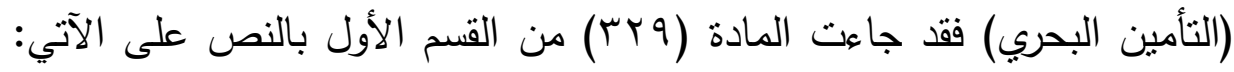
"إذا استعملت الحيلة في تقرير قيمة البضائع والأثياء المضمونة أو وقعت إفادات كاذبة في كميتها ومقدارها وتزوير في سند الشحن فيحق حينئذٍ لصاحب السكورتاه أن يكثف عن تلك البضائع ويعاينها ويقدر قيمتها ويحق له عدا عن ذلك أن يرفع دعواه على المضمن سواءً أكان بالتضمين أم التأديب جزاء جنحته أو جنايته"(آ). وتدل هذه المادة على أن نظام السكورتاه يحرم التأمين بل ويجعل عقد أو مقاولة السكورتاه باطلاً أو تصبح الوثيقة في حكم الملغاة إذا تضمنت غثناً أو تدليساً أو فعلاً عمدياً من قبل المضمن (المؤمن له). وإلى جانب هذا النظام الذي أصبح استعماله محدوداً جداً؛ فإن هنالك العرف التأميني السائد في سوق التأمين السعودي، فقد دأبت شركات التأمين العاملة في السعودية على تضمين وثائق التأمين نصاً يجعل الغش أو التدليس أو الفعل العمدي من قبل المؤمن له سبياً لإلغاء التأمين وسقوط جميع حقوق المؤمن له الناتجة من تلك الوثيقة، فقد تضدنت وثائق التأمين الصادرة عن الثركة الوطنية للتأمين التعاوني نصاً على النحو الآتي : "الاحتيال: تسقط جميع الحقوق الناشئة عن هذه الوثيقة إذا انطوت بأي وجه على احتيال أو إذا استخدم المؤمن له أو أو الأئي

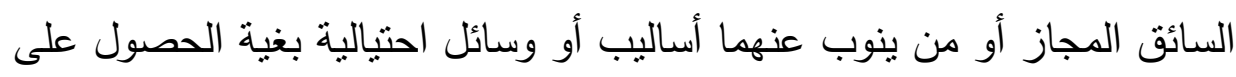
(9) محمد عبدالظاهر حسين، التأمين الإجباري، ص 919؛ عبدالقدوس الصديق، التأمين من

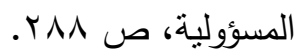

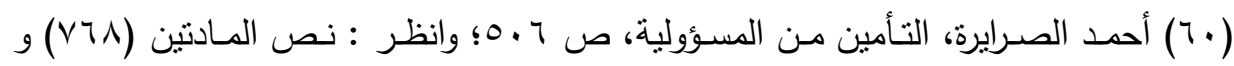

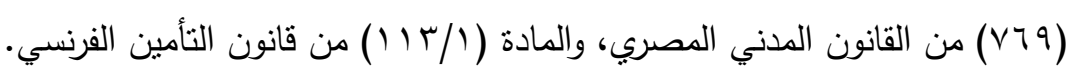

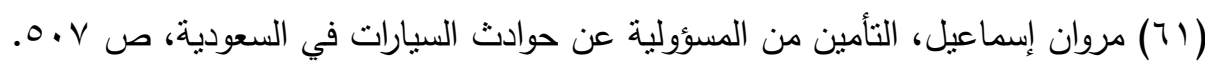

$$
(r v \cdot)
$$


المخاطر المغطاة والمخاطر المستبعدة في التأمين من المسئولية المدنية في المجال الطبي سالم عبد الله الغامدي

أي منفعة من هذه الوثثقة أو إذا نتجت الخسارة أو الضرر من جراء فعل متعدد من المؤمن له أو السائق المجاز أو بالتواطؤ مع أي منهما"(rآ).

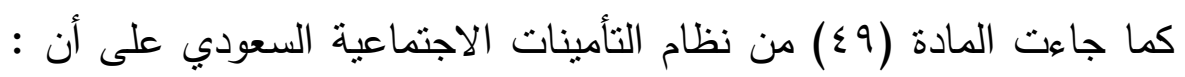
"لا تستحق التعويضات المنصوص عليها في هذا النظام إذا كان الخطر قد نشأ بصورة مقصودة ممن سيستقيد منها إذا حدث هذا الخطر نتيجة عمل جنائي قام به" فقد قررت هذه المادة حق المؤمن له في التعويض ليس فقط إذا كان الضرر قد حدث بفعله العددي (مقصوداً) بل وحتى إذا كان الضرر قد نشأ نتيجة عمل لهن جنائي قام به المؤمن له. ويلاحظ هنا استعمال المادة لكلمتي "ضرر" و "عمل" وليس خطأ ومسؤولية كما هو السائد في القوانين الأخرى(rآ). وينطبق هذا الاستبعاد على المسؤولية الطبية؛ لأنه لا خصوصية لعقد التأمين من المسؤولية الطبية، لما تقرره القواعد العامة.

كما أن وثيقة التأمين الصادرة من الثركة التعاونية للتأمين بالسعودية لم تشر إلى الخطأ العددي والغش. وكذلك لم يشر نظام مزاولة المهن الصحية في المادة (1) ولائحتها التتفيذية لاستبعاد الخطأ العددي. والمؤمن له الذي لا يجوز له له التأمين على الخطأ العدي في نطاق المسؤولية الطبية، هو الطبيب المؤمن له أو

(r7) نظام التأمين البحري السعودي (السكورتاه)، الفصل الحسادي عشر من نظـام المحكمة

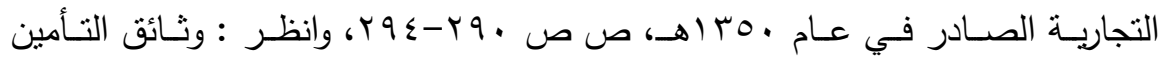

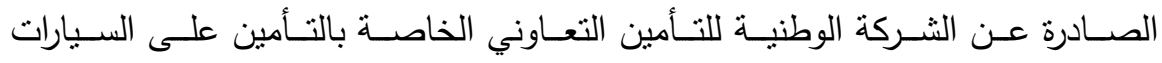

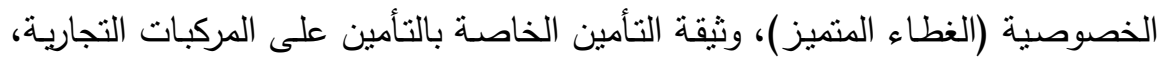

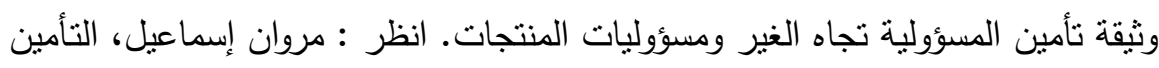

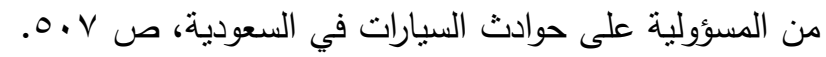

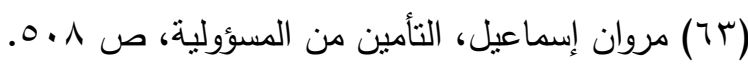

$$
(r v i)
$$


مساعدوه أو المريض المضرور (๕T)، وتحقق الخطر المؤمن منه نتيجة فعل متعدد من الطبيب أمر متصور وإن كان نادراً .

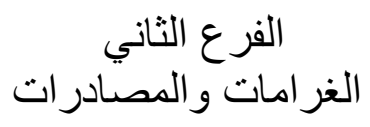

إن عقد التأمين من المسؤولية الطبية لا يغطي ما قد يحكم به على الطبيب من غرامات، أو مصادرة نتيجة لفعله الخاص، كعقوبة جنائية منصوص عليها في قانون العقوبات؛ لأن هذه العقوبة تمتاز بالصفة الشخصية، لا يمكن لشركة التأمين أن تحل محل الطبيب، ولكن تحل الثركة محل الطبيب في دفع التعويض الذي يحكم عليه، حتى ولو كانت المحكمة التي قضت بالغرامة هي نفسها التي قضت بالتعويض(70). (10) ويسري هذا الخطر، ولو كانت الغرامة المحكوم بها على الطبيب صادرة بسبب خطأ شخص آخر، كأن يستعين به أو تابع له؛ لأن الطبيب أسهم جنائياً في ذلك(T).

\section{الفرع الثالث}

$$
\text { عدم تغطية التأمين تابعي المؤمن لله }
$$

التأمين لا يغطي نتائج الأضرار التي تصيب تابعي المؤمَّن له - الطبيب أفراد أسرته إلى الدرجة الثانية؛ حيث لا يغطي التأمين الأضرار الناتجة من خطأ الطبيب، والتي تصيب والدي الطبيب، أو أحد أقاربه من الدرجة الثانية، عندما

( آ) جلال إبراهيم، التأمين من المسؤولية، ص 1 (1؛ أحمد شرف الدين، أحكام التأمين، ص

$$
\text { (70) محمد عبدالظاهر حسين، التأمين الإجباري، ص . . . 1. }
$$

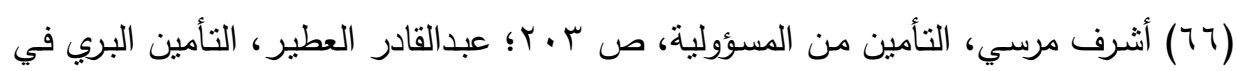

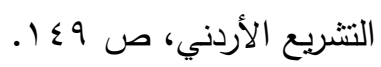

$$
(r v r)
$$


المخاطر المغطاة والمخاطر المستبعدة في التأمين من المسئولية المدنية في المجال الطبي

يقوم بمعالجتهم، حتى لا يحدث تواطؤ من قبل الطبيب بالاعتراف بقيام

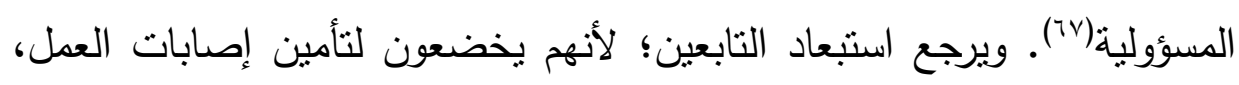
وهذا الاستبعاد نصت عليه المادة الرابعة من عقد تأمين المؤمَّنين طبياً في فرنسا

(`^) (Gamm)

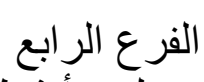

عدم تغطية التأمين لعدة أنشطة طبية متفرقة

إن التأمين في مجال المسؤولية الطبية لا يغطي الأنشطة الطبية الآتية:

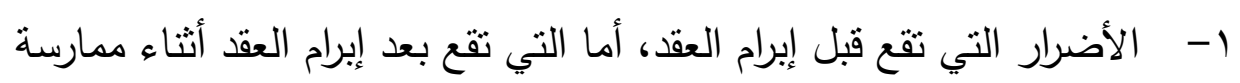
الطبيب لعمله؛ فإن التغطية تشملها.

r- لا يغطي التأمين المسؤولية الناتجة من حوادث السيارات التي تقع بفعل الطبيب المؤمن له، أو أي من الأشخاص الذين يسأل عنه؛؛ لأن هذه المسؤولية تدخل في نطاق التأمين الإجباري من المسؤولية عن حوادث

$$
\text { السيارات. }
$$

r- التأمين لا يشمل المسؤولية الناتجة من وقوع الأضرار، بسبب وقوع حريق، أو انفجار، أو تسرب مياه، أو غاز، أو حوادث كهربائية، ومن الأثياء أو

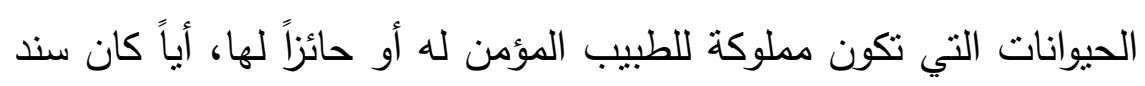

حبازته.

\section{خاتمة}

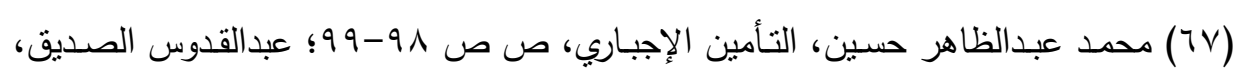

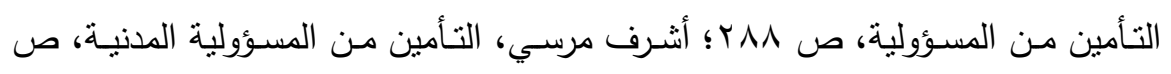

$$
\text { .r. }
$$

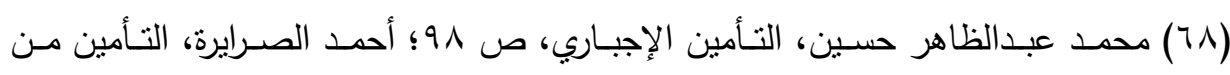

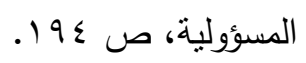

$$
(r v r)
$$


من خلال استعراض الموضوع الحالي وهو المخاطر المغطاة والمخاطر المستبعدة من التأمين من المسؤولية في المجال الطبي. فقد نبين أن المخاطر

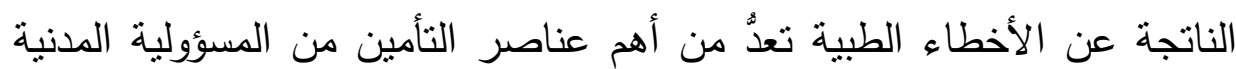

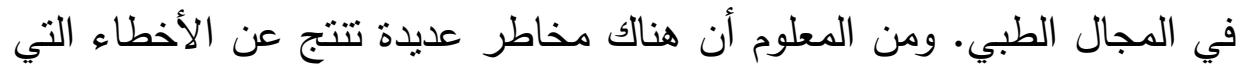

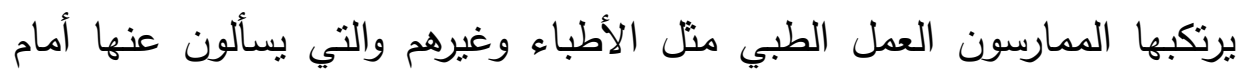
القانون المدني ويجب عليهم التعويض عنها. ولكن ليس كل المخاطر يتم تغطيتها

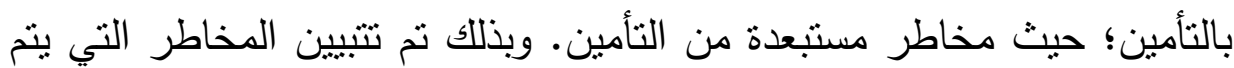
التأمين عنها والمخاطر التي لا يتم التأمين عنها. وقد أتضح من خلال الدراسة أنه يجب أن يغطي التأمين المسؤولية الطبية التقصيرية والعقدية. مع الأخذ في الاعتبار عدم جواز التأمين من الخطأ العمدي.

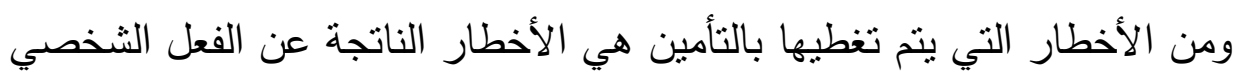

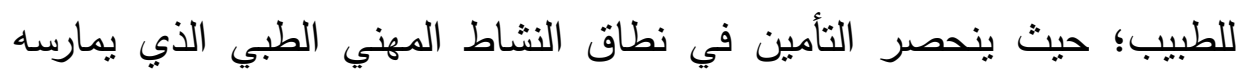

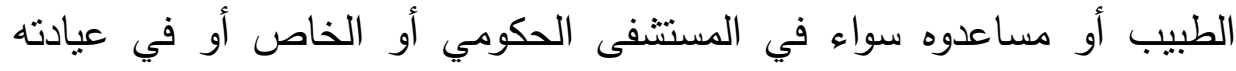

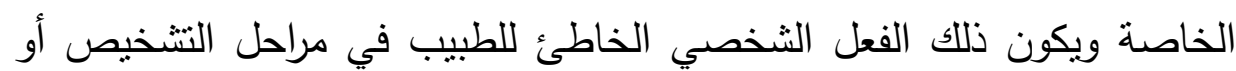
العلاج أو خلال إجراء عملية جراحية، أو استثارة طبية، أو زيارة، أو غيرها.

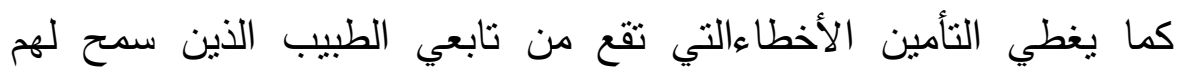

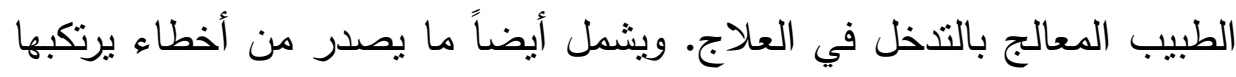

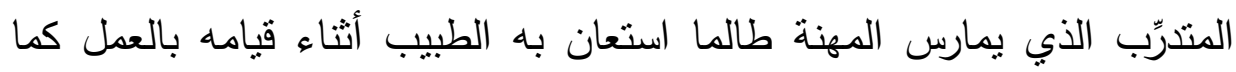

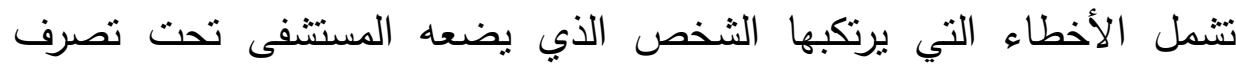
المريض، وكذلك الأخطار التي تتجم عن الثخص الذي لألي لم يمارس المهنة مادام

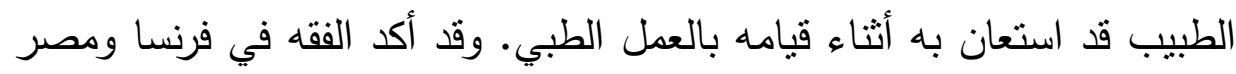

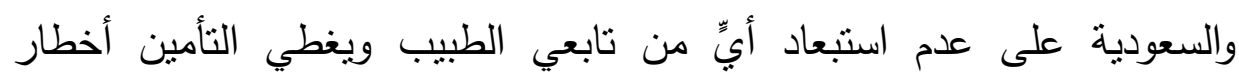
الطبيب البديل؛ حيث تقوم مسؤولية الطبيب المعالج عن أخطاء الطبيب البديل 
المخاطر المغطاة والمخاطر المستبعدة في التأمين من المسئولية المدنية في المجال الطبي

المهنية على أساس سوء اختياره له. وفي حالة استعانة الطبيب الجراح بأحد الحبراء في إجراء العملية؛ فإن هذا الغير إذا كان طبيباً يسأل بصفة شخصية عن أنساء فعله؛ فإن عقد التأمين الخاص بالغير هو الذي يغطي أفعاله.

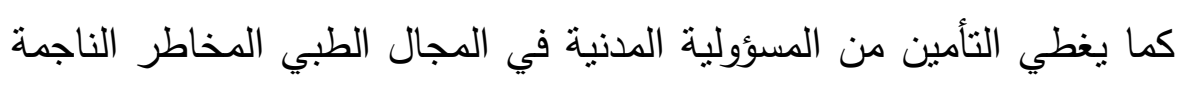
عن حوادث الآلات والأجهزة المستخدمة في النشاط الطبي للطبيب أو المستشفى لمنى المؤمَّن له. وفي مجال بنك الدم فإن التأمين يغطي المخاطر الناتجة عن حوادث التسمم الغذائي، وعن القصور الوظيفي، وعن توزيع الدم أو مشتقاته. أما الأخطار التي لا يغطيها التأمين من المسؤولية المدنية في المجال الطبي فتتمثل في: الآثار

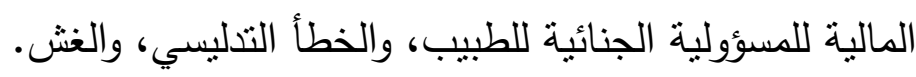
كذللك ما يغطي التأمين الأنثطة الطبية التالية: الأضرار التي تقع قبل إيرام العقد، أما التي تقع بعد إبرام العقد أثناء ممارسة الطبيب لعمله؛ فإن التغطية تشملها، ولا يغطي المسؤولية الناتجة من حوادث السيارات التي تقع بفعل الطبي المؤمن له، أو أي من الأشخاص الذين يسأل عنهم؛ لأن هذه المسؤولية تدخل في لئي نطاق التأمين الإجباري من لامسؤولية عن حوادث السيارات، ولا يشمل المسؤولية

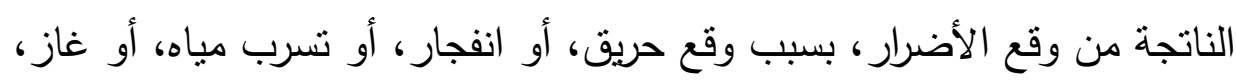

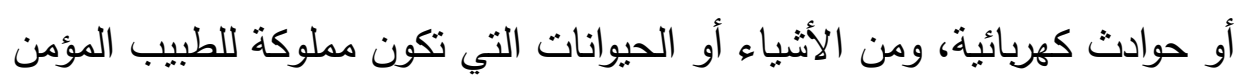

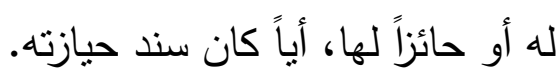

$$
\text { قائمة المر اجع }
$$

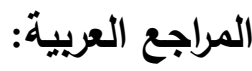

1 - الأبراشي، حسن زكي، مسؤولية الأطباء والجراحين المدنية، القاهرة، دار

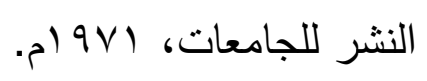

r - سعد، أحمد محمود، مسؤولية المستشفى الخاص عن أخطاء الطبيب

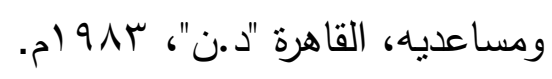

$$
(r v o)
$$


r - هاشم، عبد الراضي محمد، المسئولية المدنية للأطباء: في الفقه الإسلامي والقانون الوضعي، رسالة دكتوراه، غير منشورة، جامعة

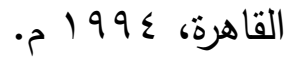

ع - بسام محتسب باله، المسؤولية الطبية المدنية والجزائية، بيروت، دار

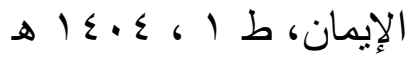

ه - منتصر ، سهير ، المسئولية المدنية عن التجارب الطبية في ضوء قواعد المسئولية المدنية للأطباء، القاهرة، دار النهضة العربي، ـ99 ام. 7 لبنان، المؤسسة الحديثة للكتاب، ع ـ . بم. - م منصور، محمد حسين، المسؤولية الطبية، الإسكندرية، دار الجامعة

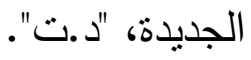
^ - مأمون عبدالرشيد ، التأمين من المسؤولية في المجال الطبي، القاهرة،

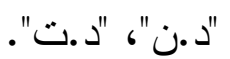

9 - الصديق، عبد القدو، "التأمين من المسؤولية وتطبيقاته الإجبارية المعاصرة"، رسالة دكتوراه، غير منشورة، كلية الحقوق، جامعة القاهرة،

$$
\text { . म) } 999
$$

• 1 - العطير، عبد القادر، التأمين البري في التتربع الأردني، عمان، دار

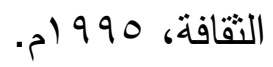

11 - إسماعيل، مروان حسن محمد، التأمين من المسؤولية عن حوادث السيارات في المملكة العربية السعودية : دراسة مقارنة بالنظام المصري

$$
\text { والانجليزي والفرنسي، "د.م"، "د.ن"، } 1 \text {. . . rم. }
$$

r للمسؤولية المدنية في ظل القواعد القانونية التقليدية، الكويت، جامعة

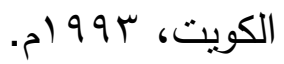

$$
(r v q)
$$


المخاطر المغطاة والمخاطر المستبعدة في التأمين من المسئولية المدنية في المجال الطبي

با - البيه، محسن عبد الحميد، حقيقة أزمة المسؤولية المدنية، ودور تأمين

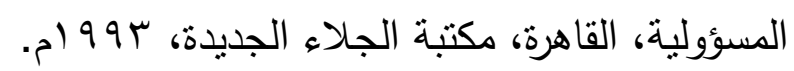

ع 1 - حسين، محمد عبد الظاهر، التأمين الإجباري من المسؤولية المدنية

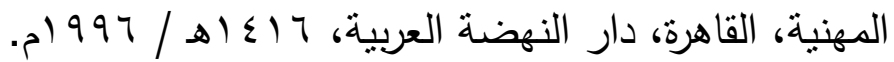

10 العقود : دراسة فقهية قضائية في مصر وفرنسا، القاهرة، دار النهضة

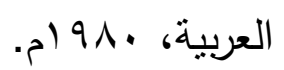

17 - الأتروشي، محمد جلال حسن، المسؤولية المدنية الناجمة عن عمليات

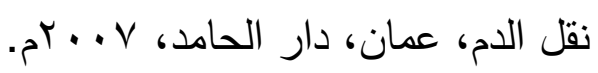

IV

$$
\text { الثقافة، } 7 \text { + . - Trم. }
$$

1 1 - مأمون، عبد الرشيد، عقد العلاج بين النظرية والتطبيق، القاهرة، دار

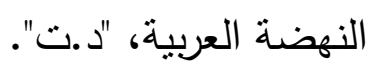

9 1 - العربي، بلحاج، النظرية العامة للالنزام في القانون المدني الجزائري،

$$
\text { الجزائر ، ديوان المطبوعات، طء، ل . . . بم. }
$$

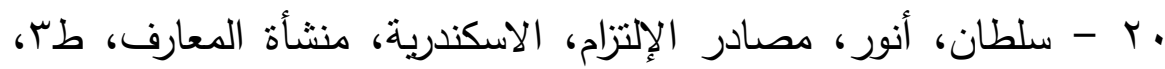

$$
\text { - ) } 9 \mathrm{~V} \text {. }
$$

ا Y - الدعجة، خالد بخيت طلال، "المسؤولية المدنية لطبيب التخدير"، رسالة

$$
\text { دكتوراه غير منشورة، جامعة عين شمس، كلية الحقوق، } 10 \text { • بrم. }
$$

r Y - مرسي، أثرف جابر ، "التأمين من المسؤولية المدنية للأطباء"، رسالة

دكتوراه، جامعة القاهرة، كلية الحقوق، غير منشورة، 999 ام.

بr - السنهوري، عبد الرزاق أحمد، الوسيط في شرح القانون المدني،

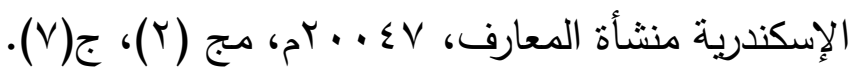

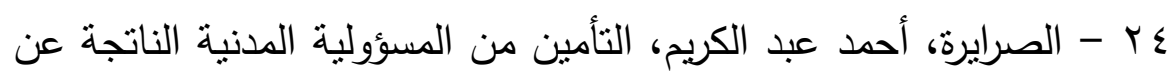

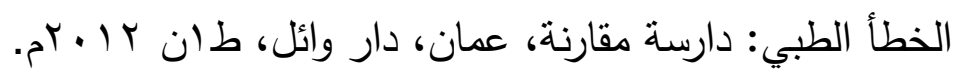

$$
\text { (rvv) }
$$


ه - الحسيني، عبد اللطيف، المسؤولية المدنية عن الأخطاء المهنية : الطبيب، والمهندس المعماري، والمقاول، والمحامي، بيروت، دار

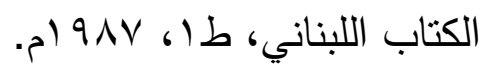

Tr - القاسم، محمد هاثم، المسؤولية الطبية من الوجهة المدنية، "د.م"،

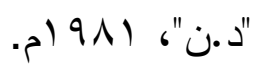

PV - نيدة، على حسين، التزامات الطبيب في العمل الطبي، القاهرة، دار

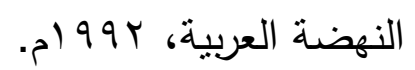

^^ - أبو جميل، وفاء حلمي، الخطأ الطبي : دراسة تحليلية فقهية وقضائية،

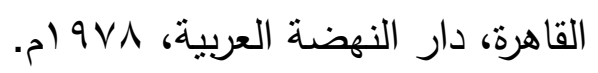

qr - مرقس، سليمان، الوافي في شرح القانون المدني، في الفعل الضار والمسؤولية المدنية، القاهرة، دار الكتب القانونية، ط ه ، 919 ام.

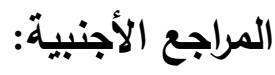

1. Lambert Faivre droit du Dommage Corporel, Systeme d'indemnistation, 5C, edition Daloz, 2004.

2. Lambert - Faivre: Droit du dommage Corporel, Systemes d'indemnisation.

3. Le Centre de transfusion sanguine est tenue d'une obligation de securite, De resultat, a l'egard de ses donneures".

4. Bruno Esnault: "Quelles solution aux Problemes d'indemnisation des victims Laccidents therapeutique responsabilite objective et assurance du risqué" 1992.

$$
(r v \wedge)
$$




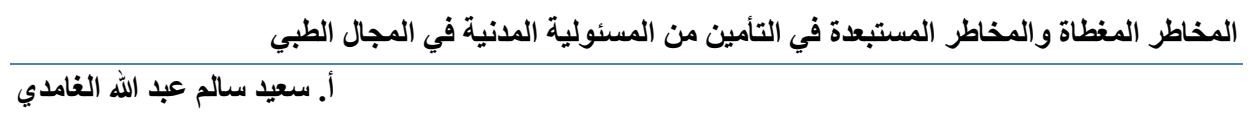

5. Cass. Civ. Ire. 6. Dec. 1994. Bull. Civ, 1994. No. 363.

6. Cass. Civ: 29 avr. 1997. R.C.A. no. 7-8 Juill- a'out 1997, Comm.

7. La garantie de L'assurance ne peut s'appliquer a un sinister d'un activite autre que celle declares par l'assure" Cass Ire civ. 29 Oct. 1997. R.C.A. no 2 fev 1998.

8. La ne concerne que le secteune d'activite Professionelle declare a l'assureur"

9. Medi - assurances Mutuelle d'assurances du corps de santé francais et Le Sou medirat "Groupe des assurances mutlulles medicales".

10. Herande, L'assurance de resoponsabilite civile professionnelle des professions liberates et prestataires des services, 1983.

11. De L'ste: Briere, "L'assurances de responsabilite des professions de santé" Jcp. 1981, 1, 3003.

12. M. Picard et A Besson, Les assurnces terrestres, tome, 1, La contrat d'assurance, sedition, Paris, 1982.

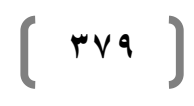

